\title{
Isolation and Identification of Bacterial Endophytes from Grasses along the Oregon Coast
}

\author{
James E. Dombrowski, Vicky G. Hollenbeck, Ruth C. Martin \\ USDA ARS Forage Seed and Cereal Research Unit, Corvallis, Oregon, USA \\ Email: *Jim.Dombrowski@ars.usda.gov
}

How to cite this paper: Dombrowski, J.E., Hollenbeck, V.G. and Martin, R.C. (2017) Isolation and Identification of Bacterial Endophytes from Grasses along the Oregon Coast. American Journal of Plant Sciences, 8, 574-601.

https://doi.org/10.4236/ajps.2017.83040

Received: September 27, 2016

Accepted: February 25, 2017

Published: February 28, 2017

Copyright $(92017$ by authors and Scientific Research Publishing Inc. This work is licensed under the Creative Commons Attribution International License (CC BY 4.0).

http://creativecommons.org/licenses/by/4.0/

\begin{abstract}
Bacterial endophytes have been shown to improve abiotic and biotic stress responses in plants. Plants growing under harsh conditions along the Oregon Coast could contain bacterial endophytes that improve persistence and growth of grasses in this environment. Thirty-four plants consisting of eight different species were collected along the Oregon coast from four different sites. Bacterial endophytes were isolated from root crown, stem and leaf tissues. A portion of the $16 \mathrm{~S}$ rRNA ITS regions of each isolate was amplified, sequenced, and used to perform a BLAST search against the nucleotide database collection at National Center for Biotechnology Information. One-hundred and thirty-three different bacterial isolates, ninety-four of which were unique, representing thirty-six different taxonomic groups were found. Over $50 \%$ of the total bacteria isolates were in just five taxonomic groups. Pseudomonads were the most predominant bacteria isolated, making up $20.3 \%$ of the total isolates, followed by Curtobacterium and Microbacterium, each at $8.2 \%, \mathrm{Ba}$ cillus at $7.5 \%$ and Xanthomomas at 6\%. Forty-seven percent (17 of 36) of the taxonomic groups contained only a single isolate. Fourteen bacterial isolates from five taxonomic groups, nine of which were from the genus Pseudomonas, were found to have 1-aminocyclopropane-1-carboxylate (ACC) deaminase activity, an enzyme associated with improving plant growth under stress. These newly discovered bacterial endophytes will be a valuable biological resource to develop approaches to increase the yield and adaptability of grasses and other crops grown in diverse environments and to meet the challenges associated with an unpredictable climate.
\end{abstract}

\section{Keywords}

Endophyte, Grasses, ACC Deaminase, Bacteria, Abiotic Stress, Salt Stress 


\section{Introduction}

Global freshwater resources are rapidly decreasing, which in many regions of the world endangers food production; roughly $70 \%$ of global freshwater consumption is by agriculture [1]. Over the past few decades there has been a significant increase in salinization of arable land [2] [3] [4]. As land becomes more limited for conventional agriculture, plants grown on marginal soils will be exposed to higher levels of mineralization and soil salinity. In a variety of plant species, transgenic lines have shown the ability to significantly increase yields and growth potential under salt stress [5] [6]. However, the negative public perception associated with transgenic approaches necessitates the development of novel approaches to find solutions to this increasing problem of diminishing water resources. Furthermore, climate change has contributed to decreased available water, which has had a negative impact on agriculture throughout the US and worldwide [7] [8]. Innovative approaches will be necessary to improve waterstress tolerance in crops and will be critical for food security. The discovery and development of novel beneficial endophytes have the potential to improve the adaptability of grasses and other crop species for production in less than ideal environments with limited water resources.

Symbiotic microorganisms are essential for almost all living organisms from insects to animals to plants. Over the last decade there has been extensive interest in the identification, isolation and elucidation of the role of these microorganisms in the rhizosphere, roots and the phyllosphere have on plant health and growth [9] [10]. The best-studied and characterized bacterial symbionts in plants are Rhizobia. These bacteria interact with the plant's root tissue to cause the development and formation of nodules, where they convert nitrogen to a plantusable form [11] [12] [13]. Bacteria have been found in almost every environment and species of plant [8] [14] [15] [16] [17]. Endophytic bacteria are found in most organs of the plant including roots, stems, leaves, seeds, fruits, tubers, ovules, as well as inside nodules [18] [19] [20]. There is a diverse range of bacterial species living in the soil associated with the roots or inside plants, as endophytes that improve the growth potential and tolerance to a wide range of biotic and abiotic stresses of the host plant [8] [9] [10] [15] [16] [20] [21] [22] [23].

Rhizospheric and endophytic bacterial species utilize a variety of mechanisms to enhance the growth of plants in different environments or in response to biotic and abiotic stresses [8] [9] [10] [16] [24] [25]. In addition to Rhizobium, there are a wide range of bacteria associated with plant roots that fix nitrogen [26] [27] [28] [29] [30]. Plant-associated bacteria have been shown to improve nutrient uptake and availability. For example, bacteria in the genera Pseudomonas, Bacillus, and Rhizobium are some of the best solubilizers of inorganic or organic phosphate, thus increasing the availability and uptake of phosphorus, a major macronutrient essential for plant growth [31]. Many of these growth enhancing endophytes can affect plant physiological processes by producing plant hormones such as indole acetic acid, gibberellins and cytokinins, which have the 
potential to enhance plant growth [32]-[37]. Another plant hormone, ethylene, is often produced in response to abiotic and biotic stress [38] [39]. Bacteria producing 1-aminocyclopropane-1-carboxylate (ACC) deaminase, which breaks down the precursor to ethylene, lowers stress ethylene levels in the plant [40]. This improves the plant's growth potential when plants are exposed to a variety of abiotic stresses [25]. The presence of growth-promoting endophytes can also improve a plant's ability to adapt and grow in soils contaminated with organic compounds and heavy metals [41]-[49]. These bacteria can alleviate the toxic effects of these compounds through decomposition, by eliminating organic pollutants in soil, by their volatilization from the plant, or by the enhanced uptake and sequestration of heavy metals from soil. These bacteria coupled with specific plant species that are able to uptake metals from the soil can provide improved approaches for phytoremediation of polluted or toxic soils. Endophytic bacteria have also been shown to be effective biological control agents against different pathogens or organisms. They utilize a range of mechanisms, including competition or exclusion, production of inhibitory compounds, and induction of systemic resistance for disease suppression in host plants [22] [50]-[56]. In addition to the production of antimicrobial compounds, bacterial endophytes also provide a valuable resource for a wide range of natural products [56] [57] [58] [59]. While some of these compounds play a role in defense, others mediate the bacteria's interaction with the host plant. Some of these compounds alter gene expression and stress-tolerance pathways within the plant, but for many of these bioactive compounds their actual role or purpose still needs to be elucidated.

A diverse array of bacterial endophytic species have already been isolated and identified from a wide range of plant species and many of these isolates have been shown to improve growth and tolerance to biotic and abiotic stresses in plants [8] [10] [15] [16] [22] [23]. Furthermore, much emphasis has been placed on the isolation of bacterial endophytes from vegetable and cereal crop species and on how these endophytes improve growth and stress tolerance in these plants. In addition to the plant species, the environment or stress the plant is exposed to will influence the type of bacteria populating the plant. In desert terrains, endophytic bacteria isolated from cardon cactus were found to promote the establishment of seedlings and plant growth on igneous rocks without soil [60]. Halotolerant bacteria isolated from saline habitats were shown to increase salt tolerance of inoculated plants [61] [62]. Endophytic bacteria were isolated and identified in three plants from the low arctic tundra and were subsequently shown to be cold-adapted and host-plant specific [63]. Growth-promoting heavy metal-resistant endophytic bacteria were isolated from two copper-tolerant plant species growing on copper mine wasteland [44]. Similarly, heavy metal-resistant bacterial endophytes isolated from the Cadmium-hyper accumulator Solanum nigrum $\mathrm{L}$. found growing on mine tailings, these bacteria were found to improve growth and resistance to different heavy metals in test plants [45]. Endophytic bacteria were isolated from plants growing in hydrocarbon contaminated soils, these endophytes were shown to enhance growth and were capable of degrading 
a wide range of hydrocarbons [49] [64]. Additionally, endophytic nitrogen-fixing bacteria that were isolated from dune grasses growing along the Oregon coast may contribute to the growth and persistence of these grasses on nutrient-poor sand [29].

Outside of sugarcane and the cereal grasses, there has been very little effort to investigate the diversity of bacterial populations in forage and turf related species [8] [15] [16] [17] [29] [49] [65] [66]. Grasses are found growing in a diverse range of environments from Antarctica, to the prairies, in alpine regions, to hot springs, to coastal shores, and even in the desert. Therefore grasses provide a unique opportunity and resource to isolate novel beneficial bacterial endophytes from plants associated with a specific environment, or plants providing an ecological niche, or plants exposed to specific types of stress. Furthermore, most of the current research on identifying plant growth-promoting bacteria that can improve growth under saline conditions has focused on isolating bacteria from the rhizosphere and the surrounding soils where the plant is growing. Far less has been done on the isolation and identification of endophytic bacteria from plants where they may impart these same benefits.

Grasses growing along the Oregon coast are exposed to poor quality soil, salinity and a variety of other abiotic and biotic stresses. In order to survive in this high stress environment, these grasses may contain an unique population of bacterial endophytes, which enhance the plant's ability to grow and survive. The long-term goal of this study is to identify bacterial endophytes that have the potential to increase stress tolerance, growth, and persistence in diverse environments for grasses and other crop species. This paper describes the initial isolation and identification of bacterial endophytes from various grasses found growing in sandy soils along the Oregon coast exposed to saline environments.

\section{Materials and Methods}

\section{$\underline{\text { Plant Collection and Endophyte Isolation }}$}

Various grass species found growing in areas exposed to ocean spray, mists and tides were collected at four different sites along the Oregon coast. Sites designated using the UTM(Universal Transverse Mercator) coordinate system were located near Harbor Vista (UTM Easting 409358.11; UTM Northing 4874316.08; UTM Zone 10T), Coos Bay (UTM Easting 394491.19; UTM Northing 4805343.08; UTM Zone 10T), Bob Creek Wayside (UTM Easting 411168.70; UTM Northing 4899584.52; UTM Zone 10T), and Yachats (UTM Easting 412067.47; UTM Northing 4906654.63; UTM Zone 10T) (Table 1). Identifications of collected plant species were confirmed with the assistance of Dr. Richard Halse at Oregon State University Herbarium.

All collected plants samples were stored in plastic bags in a cooler on ice after collection and stored at $4^{\circ} \mathrm{C}$ until processing. Samples were processed within 48 $\mathrm{h}$ of collection as described in [67]. Briefly, plants were rinsed with water to remove soil and debris, dead or damaged plant tissue, and the majority of the roots, were removed prior to processing. The remaining plant was dissected by 
tissue type corresponding to the root crown, stems, and leaves. Stems and root crowns were surface sterilized by placing in $90 \%$ ethanol for $1 \mathrm{~min}, 3 \%$ chlorine bleach with 2 drops of Tween-20/100ml for $3 \mathrm{~min}$, sterile double distilled water (DDW) for $1 \mathrm{~min}, 70 \%$ ethanol for $1 \mathrm{~min}$, and a quick rinse in sterile DDW. Leaf tissue was sterilized by placing leaves in $70 \%$ ethanol for $2 \mathrm{~min}, 2 \%$ bleach for 3 min, sterile DDW for $1 \mathrm{~min}$, followed by a quick dip in $90 \%$ ethanol. After sterilization, the end $(\sim 2-3 \mathrm{~mm})$ of stem, leaf or root crown was cut off and discarded. The remaining sample was cut into $2-3 \mathrm{~mm}$ sections. To ensure the effectiveness of the sterilization technique, randomly selected samples from all tissue types were dipped and swirled in $500 \mathrm{~mL}$ liquid $\mathrm{LB}$ and plated onto Luria Broth (LB) agar plates, no growth was observed in any of the tested samples.

For bacterial isolation, we ground the tissue by either of the following methods: 1) Sections were placed into a sterile $1.5 \mathrm{~mL}$ Eppendorf tube with $500 \mathrm{~mL}$ of liquid LB media. The tissue was macerated using a sterile pestle. 2) Tissue sections were placed into $2 \mathrm{~mL}$ tubes containing 4 beads per tube and $500 \mathrm{~mL}$ of LB media. The tissue was macerated using the 2000 Geno/Grinder (SPEX Certiprep, New Jersey USA) for $1 \mathrm{~min}$ at setting 1100 strokes per min for stems and root crowns, and $15 \mathrm{sec}$ for leaf tissue. The ground tissue suspension was then was spread on LB agar plates and incubated at $28^{\circ} \mathrm{C}$ for 1 to 2 days.

\section{Colony Isolation and DNA Prep}

Some tissues samples (mostly leaf) yielded either very few or no isolates. Most stem and root crown tissue produced a range from ten to hundreds of colonies per plate. On plates with large numbers of bacteria, selection of colonies was based on observable differences such as color and colony morphology in order to obtain a representative sampling of the bacteria. Where possible we attempted to select at least 2 - 3 colonies per colony type per plate.

These initial bacterial cultures were sub-cultured on LB agar plates until single, isolated colonies were obtained. Single colonies were selected and grown in LB at $28^{\circ} \mathrm{C}$ until turbid (typically 24 hours). Bacterial DNA was extracted by concentrating $1.5 \mathrm{~mL}$ of cell suspension via centrifugation for $1 \mathrm{~min}$ at 14,000 rpm using a Eppendorf 5417C centrifuge followed by resuspension in $400 \mathrm{uL}$ CLS-TC lysis buffer (MP Biomedicals, Santa Ana, CA) with $0.1 \mathrm{mg} / \mathrm{mL}$ Proteinase $\mathrm{K}$ and $1 \mathrm{mg} / \mathrm{mL}$ Lysozyme. Samples were incubated for $10 \mathrm{~min}$ at $55^{\circ} \mathrm{C}$, followed by inactivation of Proteinases by incubating $10 \mathrm{~min}$ at $80^{\circ} \mathrm{C}$. The DNA was isolated by applying the lysates to QiagenDNeasy Plant Mini Kit purification columns followed by centrifugation for $1 \mathrm{~min}$ at 14,000 rpm using an Eppendorf 5417C centrifuge, followed by two washes with $500 \mathrm{~mL}$ Buffer AW (Qiagen, Germany), and resuspension in $50 \mathrm{uL}$ EB elution buffer (Qiagen, Germany) from the QiagenDNeasy Plant Mini Kit.

\section{Amplification of 16S Ribosomal ITS Region}

The 16S rRNA ITS region was amplified by PCR with primers derived from primer set 1 5'-AGAGTTTGATCCTGGCTCAG-3' and 5'-AAGGAGGTGAT CCAGCCGGA-3' [68]. Note: some samples gave mixed products when sequenced, so a second primer pair, primer set 2 5'AGAGTTTGATYMTGGC-3' 
and 5'-TACCTTGTTACGACTT-3' was designed to amplify the ITS region from these bacterial isolates [69]. Most amplicons were $~ 1402$ base pairs in length. The DNA was amplified using $1 \times$ HotStarTaq Master Mix (Qiagen, Germany) following the manufacturer's instructions, $20 \mu \mathrm{L}$ reaction volumes containing with $10 \mathrm{p}$ moles of each primer, $1 \mu \mathrm{L} \mathrm{DNA}$, and water to volume. Amplification was performed on an MJ Research PTC 200 (BioRad; Hercules, CA) with the following program: initial denaturation at $94^{\circ} \mathrm{C}$ for 15 minutes; 35 cycles of $94^{\circ} \mathrm{C}$ for $1 \mathrm{~min}$, annealing temperature for primer set 1 was at $60^{\circ} \mathrm{C}$ and for primer set 2 at $56^{\circ} \mathrm{C}$ for 1 minute, $72^{\circ} \mathrm{C}$ for $1 \mathrm{~min}$; and a final extension at $72^{\circ} \mathrm{C}$ for $10 \mathrm{~min}$; and then kept at $4^{\circ} \mathrm{C}$ until removal.

Amplification was verified by gel electrophoresis and those with multiple bands were run on agarose gels, followed by excision of desired products and purification with Qiagen Gel Purification Kits. The PCR products were run on a $1 \%$ TAE agarose gels to analyze purity. Single-band products were purified using Qiagen PCR Purification Kit (Qiagen, Germany); those with multiple bands were run on $1 \%$ TAE agarose gels, followed by excision of desired products and purification with Qiagen Gel Purification Kits (Qiagen, Germany). All samples were measured on a Nanodrop for quantity and quality.

\section{Sequencing and Identification}

Sanger sequencing was performed at either Oregon State University's Center for Gene Research and Biocomputing, Corvallis, OR or by Eurofins, Louisville, KY. Sequencing primers used were 5'-GTATTACCGCGGCTGCTGG-3' for products amplified with primer set 1, and 5'-ATTACCGCGGCTGCTGG-3' for products amplified with primer set 2 . This generated sequences of $433-460$ base pairs in length. Resulting fasta files were subjected to a Nucleotide-Nucleotide BLAST 2.2.29+ search against the $\mathrm{nr} / \mathrm{nt}$ database using command line syntax with default settings at National Center for Biotechnology Information (NCBI, GenBank; www.ncbi.nih.gov).

\section{ACC Deaminase Activity Assay}

The bacterial isolates were screened for ACC utilization. We followed the protocol described in [70] [71] with the following modifications: Bacteria were first grown on $\mathrm{LB}$ plates at $28^{\circ} \mathrm{C}$ until colonies were visible, 24 - 48 hours depending on rate of growth of a particular isolate. Selected colonies from the bacterial plates were grown in liquid cultures in LB media to visible turbidity, 24 48 hours prior to use in the assay. Transformation bacterium E. coli DH5 $\alpha$ was used as a negative control in addition to the blank sample since it was confirmed to show no ACC utilization via this assay. A Pseudomonas strain with known ACC deaminase activity (Joyce Loper USDA-ARS Corvallis Oregon and Ann Kennedy, USDA-ARS Pullman WA) was used as a positive control on all plates. Quantities of the 10-fold dilution of DF-ACC medium [70] [71] culture and ninhydrin reagent were increased on the reaction plates to $80 \mu \mathrm{l}$ and $160 \mu \mathrm{l}$ per well respectively for improved results ( $\mathrm{Q}$. An, personal communication). Each diluted supernatant was run in duplicate. After visual scoring, absorbance was measured at $595 \mathrm{~nm}$ with the Bi-Tek EL808 plate reader. 


\section{Results and Discussion}

Thirty-four different plant samples comprising eight different genera of grasses were collected from various sites along the Oregon coast. Table 1 shows the plant genera and their distribution for each site; four plants collected from Coos Bay, fourteen from Harbor Vista, nine from Bob Creek Wayside, and seven from Yachats. The two most prevalent grasses collected from these locations were Bromus and Festuca, with ten plants each. Bromus was the only genus collected from all four sites. A total of 173 culturable single colony isolates were generated from the various tissue types from 34 grass plants collected along the Oregon coast. DNA was isolated from each of these cultures and a portion of the 16S rRNA ITS region was PCR-amplified and sequenced. The resulting sequences were BLASTed against the nucleotide database collection at National Center for Biotechnology Information. Based on their 16S rRNA ITS sequences, duplicate isolates from each individual plant (same strain originating from the same plant, found in any tissue type) were eliminated from further analysis. This resulted in 133 individual isolates. The 133 bacterial isolates were classified into 36 taxonomic groups based on their 16S rRNA ITS sequences. The classification and distribution (plant genera and locations) of these bacterial groups are listed in Table 2 .

Based on the BLAST sequences, the isolates were classified and grouped by their lowest common taxonomic rank. Twenty-six were classified into taxonomic groups at the genus level, five were identified to the species level, four others could only be assigned to the class, order or family taxonomic rank, and three bacterial isolates could not be defined. (Supplementary Table S1, all 133 bacterial isolates are listed with their hit descriptions and sequence id information at the end of the manuscript). Over $50 \%$ of the total bacteria isolates are from just five taxonomic groups. Pseudomonads were the most predominant bacteria isolated from these grasses, making up $20.3 \%$ of the total isolates, followed by Curtobacterium and Microbacterium each at $8.2 \%$, Bacillus at $7.5 \%$ and Xanthomomas at $6 \%$, whereas $47 \%$ (17 of 36 ) of the taxonomic groups contained only a single

Table 1. Plant collection and distribution.

\begin{tabular}{cccccccc}
\hline Plant Genus & Bob Creek & Coos Bay & $\begin{array}{c}\text { Harbor } \\
\text { Vista }\end{array}$ & Yachats & $\begin{array}{c}\text { Total } \\
\text { Plants }\end{array}$ & $\begin{array}{c}\text { Total } \\
\text { Isolates }\end{array}$ & ACC+ \\
\hline $\begin{array}{c}\text { Agrostis } \\
\text { Ammophilia }\end{array}$ & & 1 & 1 & 2 & 3 & 3 & 1 \\
Bromus & 3 & 1 & 4 & 2 & 10 & 49 & 5 \\
Descampsia & & 1 & 6 & 1 & 1 & 7 & \\
Festuca & 3 & 1 & & & 10 & 41 & 7 \\
Hordeum & 1 & & & & 1 & 7 & \\
Lolium & 2 & & 2 & 2 & 6 & 15 & \\
Phalaris & 9 & 4 & 14 & 7 & 34 & 133 & 14 \\
Totals: & 9 & & & & & & \\
\hline
\end{tabular}


Table 2. Classification and distribution of bacterial isolates.

\begin{tabular}{|c|c|c|c|c|c|c|}
\hline Taxonomic Group ${ }^{*}$ & & $\begin{array}{l}\text { Total \# } \\
\text { isolates }\end{array}$ & $\begin{array}{l}\text { Unique } \\
\text { Seq }\end{array}$ & $\mathrm{ACC}+$ & Location $(\mathrm{s})^{* *}$ & $\begin{array}{c}\text { Plant } \\
\text { Genus }{ }^{* * *}\end{array}$ \\
\hline Agreia & G & 4 & 2 & & $\mathrm{H}$ & B F P \\
\hline Achromobacter & G & 1 & 1 & 1 & $\mathrm{C}$ & $\mathrm{Am}$ \\
\hline Actinomycetales bacterium & $\mathrm{O}$ & 2 & 2 & & $\mathrm{CY}$ & B D \\
\hline Aeromicrobium & G & 1 & 1 & & B & B \\
\hline alpha proteobacterium & $\mathrm{C}$ & 2 & 2 & & $\mathrm{Y}$ & $\mathrm{Ag} \mathrm{B}$ \\
\hline Alter erythrobacter & G & 1 & 1 & 1 & $\mathrm{Y}$ & $\mathrm{Ag}$ \\
\hline Agrobacterium & G & 1 & 1 & & $\mathrm{C}$ & B \\
\hline Bacillus & G & 10 & 6 & & C B H Y & Ag Am B F P \\
\hline Betaproteobacteria bacterium & $\mathrm{C}$ & 1 & 1 & & $\mathrm{Y}$ & $\mathrm{P}$ \\
\hline Bordetella & G & 1 & 1 & & $\mathrm{C}$ & B \\
\hline Brachybacterium tyrofermentans & Sp & 1 & 1 & & $\mathrm{H}$ & $\mathrm{F}$ \\
\hline Brevundimonas & G & 1 & 1 & & $\mathrm{Y}$ & B \\
\hline Caryophanon & G & 1 & 1 & & $\mathrm{H}$ & $\mathrm{F}$ \\
\hline Chryseobacterium & G & 1 & 1 & & $\mathrm{Y}$ & $\mathrm{D}$ \\
\hline Clavibacter michiganensis & $\mathrm{Sp}$ & 1 & 1 & & $\mathrm{H}$ & B \\
\hline Curtobacterium & G & 11 & 4 & & B C H Y & B D F P \\
\hline Enterobacteriaceae bacterium & $\mathrm{F}$ & 1 & 1 & & B & $\mathrm{F}$ \\
\hline Exiguobacterium & G & 4 & 3 & & $\mathrm{H} \mathrm{Y}$ & B F \\
\hline Flavobacterium & G & 3 & 3 & & B H Y & B F P \\
\hline Frigoribacterium faeni & Sp & 3 & 3 & & B C Y & B F \\
\hline Luteimonas aestuarii & Sp & 1 & 1 & & $\mathrm{H}$ & $\mathrm{F}$ \\
\hline Lysobacter & G & 1 & 1 & & $\mathrm{H}$ & $\mathrm{F}$ \\
\hline Kocuria & G & 3 & 3 & & B H & F P \\
\hline Microbacterium & G & 11 & 9 & & B C H Y & Am B D F H P \\
\hline Oerskovia turbata & Sp & 1 & 1 & & $\mathrm{Y}$ & B \\
\hline Pantoea & G & 5 & 5 & & B C & B F \\
\hline Plantibacter & G & 7 & 2 & & C H Y & B D H P \\
\hline Pseudomonas & G & 27 & 13 & 10 & B C H Y & Am B D F H P \\
\hline Ralstonia & G & 2 & 2 & & B C & Am P \\
\hline Rhizobium & G & 4 & 4 & 1 & B H Y & Am F P \\
\hline Rhodococcus & G & 2 & 2 & 1 & $\mathrm{CY}$ & B P \\
\hline Roseomonas & G & 1 & 1 & & $\mathrm{C}$ & $\mathrm{H}$ \\
\hline Sphingomonas & G & 1 & 1 & & B & B \\
\hline Stenotrophomonas & G & 5 & 4 & & H Y & Am B F P \\
\hline Uncultured bacterium & nd & 3 & 3 & & $\mathrm{~B} \mathrm{C} \mathrm{H}$ & Am F P \\
\hline Xanthomonas & G & 8 & 5 & & $\mathrm{~B} \mathrm{C} \mathrm{H}$ & B F H L \\
\hline Total Taxa: 36 & & 133 & 94 & 14 & & \\
\hline
\end{tabular}

${ }^{*}$ Taxonomic Group: $\mathrm{C}=$ Class; $\mathrm{O}=$ Order; $\mathrm{F}=$ Family; $\mathrm{G}=$ Genus; $\mathrm{Sp}=$ Species nd = not determined; ${ }^{* *}$ Location: $\mathrm{B}=$ Bob Creek Wayside; $\mathrm{C}=$ Coos Bay; $\mathrm{H}=$ Harbor Vista; $\mathrm{Y}=$ Yachats; ${ }^{* *}$ Plant Genus: Ag = Agrostis; Am = Ammophilia; $\mathrm{B}=$ Bromus; $\mathrm{D}=$ Descampsia; $\mathrm{F}=$ Festuca; $\mathrm{H}=$ Hordeum; $\mathrm{L}=$ Lolium; $\mathrm{P}=$ Phalaris. 
isolate. A survey of endophytic bacteria isolated from dune grasses collected from the Oregon Coast also found that that Pseudomonads were the most prevalent microorganism [29]. In addition, in a study of endophytic bacteria isolated from Lolium perenne plants growing in hydrocarbon contaminated soil, Pseudomonas, Bacillus and Curtobacterium were the most prevalent bacteria isolated [49]; and in poplar grown under field conditions, the most abundant genera among the isolated bacterial endophytes were Pseudomonas and Curtobacterium [72]. Furthermore we found that potentially pathogenic strains of bacteria were present in some of the grasses we collected along the Oregon Coast, such as Clavibacter michiganensis and members of the genus Xanthomonas. This is not surprising since these types of pathogens infect the surface of the plant and can live inside the plant, so they would have survived the sterilization treatments.

Sixty-seven percent of the bacteria were isolated from root crown tissue, 23\% were derived from the stem, and only $10 \%$ came from leaf tissue (Table 3 ). Note, in Table 3, three plants had the same isolate in two different tissue types, which added three additional isolates to the overall total. This is not surprising, since most colonization of plants occur initially via the roots, and in most plants the roots have the highest number of endophytes when compared other parts of plant. [15] [16] [73] [74]. Not surprisingly, the genera containing the largest number of isolates, Pseudomonads, Curtobacterium, Microbacterium and Bacillus, were found in grasses at all the sites, while 19 taxonomic groups were isolated from plants found at only one of the locations. No taxonomic group had members isolated from all the eight plant genera. Two of the most predominant genera, Pseudomonas and Microbacterium, were found in six of the eight plant genera. Bacteria from the taxonomic groups, Actinomycetales bacterium, Flavobacterium, Frigoribacterium faeni, Ralstonia, Rhodococcus and Uncultured bacterium with two or three isolates each, had each isolate originating from different locations. All but Frigoribacterium faeni were isolated from different plant genera as well. Agrostis had the lowest number of isolates per plant (one each), but all the isolates were from different genera, Alpha proteobacterium, Alter erythrobacter and Bacillus, while the only Lolium plant yielded only two isolates belonging to Xanthomonas genus. A single Bromus plant collected from the Coos Bay site yielded fourteen distinct isolates belonging to ten different taxonomic groups; similarly a single Bromus plant from the Yachats site generated eleven different isolates from seven different taxonomic groups. The only Descampsia plant collected yielded seven different isolates from six different taxonomic groups.

Table 3. Tissue distribution of bacterial isolates.

\begin{tabular}{cc}
\hline Tissue & Total isolates \\
\hline Root Crown & 91 \\
Stem & 31 \\
Leaf & 14 \\
Total & 136 \\
\hline
\end{tabular}


Table 4. Distribution of bacterial isolates by collection site.

\begin{tabular}{ccccc}
\hline Location & Total Isolates & Total Plants & Avg. \# Isolates/Plant & Total Taxa \\
\hline Bob Creek Wayside & 28 & 9 & 3.1 & 15 \\
Coos Bay & 30 & 4 & 7.5 & 16 \\
Harbor Vista & 43 & 14 & 3.1 & 18 \\
Yachats & 32 & 7 & 4.6 & 18 \\
\hline
\end{tabular}

Interestingly, while fewer plants were collected at Coos Bay, they displayed a much higher average number of isolates per plant (7.5, Table 4) than plants from other areas (3.1 - 4.6 isolates/plant). However this higher number of isolates per plant from grasses collected from Coos Bay was similar to the findings for fungal endophytes isolated from these same plants [67]. Despite differences in the total number of isolates per location as well as the total number of plants per location, all four locations yielded a similar number of taxonomic groups per locale; from 15 at Bob Creek Wayside, 16 at Coos Bay and 18 for both Harbor Vista and Yachats. These numbers suggest that plants collected from Coos Bay appear to have on average a higher number of isolates per plant, but also a greater diversity of bacteria than found in plants from the other three sites. One can speculate why this would be, the Coos Bay site was more remote and there were no cultivated grasses growing in close proximity to where the plants were collected. This was not the case at the other sites, where some of the samples collected could have been escapes from cultivated grasses, from nearby home sites, recreational areas, or erosion-control landscaping. This could potentially affect the types of endophytes and grasses isolated from each area. Furthermore, while the average number of isolates per plant provides some insight into the diversity present at a particular location, it still is only a rough approximation. Since the number of bacteria from some tissue types in some plants could yield hundreds of bacteria per plate. A particular bacterial plate could yield hundreds of colonies and only a representative sample from each plate was selected. Furthermore the bacteria isolated were only those that were culturable, therefore these numbers by no means represent the totality or diversity of bacteria that may be present in any of the plants collected.

In order to determine the number of unique isolates identified in our study, we aligned and compared the partial 16S rRNA ITS sequences in each taxonomic group for the 133 bacterial isolates. Based on this analysis, we identified potential identical isolates present in different plants in nine of the 36 taxonomic groups (Table 5(a) and Table 5(b)). Each unique sequence was assigned an arbitrary letter within a taxonomic group. For example, in Bacillus, there were ten total isolates but only six unique sequences. In sequence groups A-E there was only a single isolate, while in group F, five isolates had the same ITS sequence but they were isolated from different plants (see Supplemental Table S1). Table 5(a) and Table 5(b) summarize only the sequence groups from each taxonomic group that have more than one isolate. By eliminating these duplicate isolates, the total number of unique bacterial isolates was reduced to 94 . For example in 
Table 5. (a) Distribution of the same bacteria isolates found in different plants by location; (b) Distribution by plant genera containing the same bacteria isolates.

(a)

\begin{tabular}{|c|c|c|c|c|c|}
\hline Taxonomic Group & Seq Group & Bob Creek ${ }^{\star}$ & Coos Bay & Harbor Vista ${ }^{\star}$ & Yachats* \\
\hline Agreia pratensis & $\mathrm{B}$ & & & 3 & \\
\hline Bacillus & $\mathrm{F}$ & 1 & 1 & 2 & 1 \\
\hline Curtobacterium & $\mathrm{D}$ & 4 & 2 & 1 & 1 \\
\hline Exiguobacterium & $\mathrm{C}$ & & & & 2 \\
\hline Microbacteriaceae & $\mathrm{F}$ & & 1 & & 1 \\
\hline Plantibacter & B & & 1 & 2 & 3 \\
\hline Pseudomonas & B & 1 & & $3(3)$ & $1(1)$ \\
\hline Pseudomonas & $\mathrm{C}$ & 2 & 1 & 1 & 1 \\
\hline Pseudomonas & $\mathrm{D}$ & & & $1(1)$ & 2 \\
\hline Pseudomonas & $\mathrm{H}$ & $1(1)$ & & $1(1)$ & $1(1)$ \\
\hline Pseudomonas & M & & 1 & $1(1)$ & 1 \\
\hline Stenotrophomonas & $\mathrm{D}$ & & & 1 & 1 \\
\hline Xanthomonas & $\mathrm{E}$ & 1 & 1 & 1 & \\
\hline
\end{tabular}

Letter designates isolate with same ITS Sequence but isolate found in a different plant. Numbers represent the \# of isolates found with that particular sequence. ${ }^{*}$ The number in parenthesis represents the \# of isolates displaying ACC deaminase activity.

(b)

\begin{tabular}{|c|c|c|c|c|c|c|c|c|c|}
\hline Taxonomic Group & Seq Group & Agrostis & Ammophilia & Bromus $^{*}$ & Descampsia & Festuca $^{*}$ & Hordeum & Lolium & Phalaris \\
\hline Agreia pratensis & B & & & 1 & & 1 & & & 1 \\
\hline Bacillus & $\mathrm{F}$ & 1 & & 2 & & 1 & & & 1 \\
\hline Curtobacterium & $\mathrm{D}$ & & & 3 & & 4 & & & 1 \\
\hline Exiguobacterium & $\mathrm{C}$ & & & 2 & & & & & \\
\hline Microbacteriaceae & $\mathrm{F}$ & & & 1 & 1 & & & & \\
\hline Plantibacter & B & & & 3 & 1 & & 1 & & 1 \\
\hline Pseudomonas & B & & & $2(2)$ & & $3(2)$ & & & \\
\hline Pseudomonas & $\mathrm{C}$ & & 1 & 1 & 1 & 2 & & & \\
\hline Pseudomonas & $\mathrm{D}$ & & & 2 & & $1(1)$ & & & \\
\hline Pseudomonas & $\mathrm{H}$ & & & $2(2)$ & & $1(1)$ & & & \\
\hline Pseudomonas & M & & & 1 & & $1(1)$ & & & 1 \\
\hline Stenotrophomonas & $\mathrm{D}$ & & & 1 & & 1 & & & \\
\hline Xanthomonas & $\mathrm{E}$ & & & & & 1 & 1 & 1 & \\
\hline
\end{tabular}

Letter designates isolate with same ITS Sequence but isolate found in a different plant. Numbers represent the \# of isolates found with that particular sequence. ${ }^{\star}$ The number in parenthesis represents the \# of isolates displaying ACC deaminase activity.

the genus Pseudomonas there were 27 individual isolates, but after aligning their ITS sequences, it was determined that only 13 of the isolates were unique. Of the 13 unique bacterial isolates, five of them included a number of isolates with identical sequences, even though they were found in different plants, either from 
the same site or in different locations (Table 5(a)). Specific bacterial isolates from the genera Bacillus, Curtobacterium and one from Pseudomonas were found in plants at all four sites (Table 5(a)). While Bacillus F, Plantibacter B and Pseudomonas $\mathrm{C}$ isolates were found in four different plant genera. It should be noted that the four collection sites were distributed along a 75 mile stretch of the Oregon coast, ranging from Coos Bay to Yachats. These data give some insight into how widespread or common some of these bacterial endophytes are in plants along the Oregon coast, and how amenable a particular isolate might be at colonizing different plant species. Surprisingly, one of the isolates from Pseudomonas seq group B, isolated from Bob Creek Wayside did not display ACCdeaminase activity (Table $5(\mathrm{a})$ ). It is possible that it was only a closely related strain to the other members of the group, but could not be distinguished from them since only a partial sequence $(433-460 \mathrm{bp}$ ) for the $16 \mathrm{~S}$ rRNA region was used for its identification; or it is possible that this particular isolate had a potential mutation that affected its ability to produce an active enzyme. It should be noted that using partial sequence information can make it difficult to definitively identify a species [75].

\section{Identification of Isolates displaying ACC Deaminase Activity}

The main goal of this study was to isolate and identify endophytic bacteria that can increase the growth and persistence of plants when subjected to salt stress. Growth-promoting bacteria use a variety of mechanisms to improve the growth potential of the plant in different environments and stresses [8] [9] [10] [16] [24] [25]. One of the key mechanisms utilized by plant growth-promoting bacteria is the lowering of plant stress ethylene levels by the enzyme 1-aminocyclopropane-1-carboxylate (ACC) deaminase [25] [40]. Under stress, plants produce higher levels of ethylene, which can inhibit their growth and reduce overall health [38] [39]. The ACC-deaminase enzyme cleaves the ethylene precursor, ACC, thereby decreasing ethylene levels in the plant. This in turn promotes growth and improves the plant's performance under stress [25] [40]. Furthermore, in addition to the modulation of ethylene levels, the synergistic interactions between ethylene and auxin during stress also regulate plant and root growth [25]. These ACC-deaminase containing bacteria not only promote plant growth, they also have been shown to improve the plant's tolerance to salt stress and other biotic and abiotic stresses including: drought, flower wilting, flooding, metals, organic contaminants, and pathogens [8] [9] [25]. Therefore endophytic bacteria possessing ACC deaminase activity may provide tolerance to more than one type of stress, which could improve the plant's adaptability to an ever-changing environment.

Realizing the value of this particular enzyme and its link to stress tolerance, we tested our endophytic bacterial isolates for ACC-deaminase activity [70] [71]. Our analysis found that 14 of 133 isolates tested positive for ACC deaminase activity (Table 6). Five different taxonomic groups had a positive isolate, with Pseudomonas containing 10 of the 14 positive isolates; Achromobacter, Altererythrobacter, Rhodococcus and Rhizobia each had one positive isolate. 
Table 6. Bacterial isolates displaying ACC deaminase activity.

\begin{tabular}{|c|c|c|c|c|c|}
\hline Taxonomic Group & Seq Group ${ }^{*}$ & Seq ID ID $^{* *}$ & Location & Plant Genus & Tissue $^{* * *}$ \\
\hline Achromobacter & A & CB3BRC-3B & Coos Bay & Ammophilia & $\mathrm{RC}$ \\
\hline Altererythrobacter & A & YH7SS-1A & Yachats & Agrostis & S \\
\hline Rhizobium & $\mathrm{C}$ & BS7RC-2A & Bob Creek Wayside & Festuca & $\mathrm{RC}$ \\
\hline Rhodococcus & B & CB2ALF-2A & Coos Bay & Bromus & $\mathrm{L}$ \\
\hline Pseudomonas & B & HV11RC-1A & Harbor Vista & Bromus & $\mathrm{RC}$ \\
\hline Pseudomonas & B & YH3RC-7A & Yachats & Bromus & $\mathrm{RC}$ \\
\hline Pseudomonas & B & HV9RC-3A & Harbor Vista & Festuca & $\mathrm{RC}$ \\
\hline Pseudomonas & B & HV6RC-2A & Harbor Vista & Festuca & $\mathrm{RC}$ \\
\hline Pseudomonas & $\mathrm{D}$ & HV13RC-1A & Harbor Vista & Festuca & $\mathrm{RC}$ \\
\hline Pseudomonas & $\mathrm{E}$ & BS5RC-9A & Bob Creek Wayside & Festuca & $\mathrm{RC}$ \\
\hline Pseudomonas & $\mathrm{H}$ & BS5RC-8A & Bob Creek Wayside & Festuca & $\mathrm{RC}$ \\
\hline Pseudomonas & $\mathrm{H}$ & HV14SS-3A & Harbor Vista & Festuca & S \\
\hline Pseudomonas & $\mathrm{H}$ & YH3RC-12C-A & Yachats & Bromus & $\mathrm{RC}$ \\
\hline Pseudomonas & M & HV11RC-3A & Harbor Vista & Bromus & $\mathrm{RC}$ \\
\hline
\end{tabular}

${ }^{\star}$ Letter designates isolate with same ITS Sequence but isolate found in a different plant. ${ }^{\star *}$ Seq ID: Location, Plant \#, TissueType - Isolate \#. ${ }^{\star * \star}$ RC $=$ Root Crown; $\mathrm{S}=$ Stem; $\mathrm{L}$ = Leaf.

While Pseudomonas was by far the most prevalent genus found in our study, this is not surprising since there have been many reports of different growthpromoting Pseudomonas species that display ACC-deaminase activity and that have been shown to improve growth and stress tolerance [8] [9] [23]. An ACC-deaminase-active Pseudomonas fluorescens strain mediates saline resistance in groundnut plants [76]. Similarly, Pseudomonas putida containing ACC-deaminase was shown to improve growth and yield of wheat under saltstressed conditions [77]. In addition strains of ACC deaminase-producing Pseudomonas fluorescens and Pseudomonas putida were shown to improve growth and alleviate the effects of salt stress in canola [78]. Furthermore ACCdeaminase-containing Pseudomonas syringae and Pseudomonas fluorescens improved the growth of maize plants under high-salt conditions [79]. Additionally, studies have demonstrated the role of various ACC deaminase-containing Pseudomonas bacteria in improving growth and tolerance to plants subjected to salt stress. These include Pseudomonas syringae and Pseudomonas fluorescens in mung bean [80], Pseudomonas putida and Pseudomonas fluorescens in wheat [81], and Pseudomonas mendocina containing a plasmid carrying the gene encoding ACC deaminase in tomato [82]. In one recent study, ACC-deaminasecontaining bacterial endophytes, Pseudomonas fluorescens and Pseudomonas migulae, and their ACC-deaminase-deficient mutants were compared for their ability to improve growth of tomato plants under salt stress. The ACC-deaminase-active strains improved growth, while their mutant counterparts did not. Since the only difference between the wild-type and mutant bacterial endophytes was ACC deaminase activity, this indicated that ACC-deaminase was directly 
responsible for the improved growth to salt-stressed tomato plants [83]. Pseudomonas strains have also been shown to be effective biocontrol agents against pathogenic fungi and bacteria [51] [55] [83] [84] [85], as well as other types of stresses. For example, in Lolium perenne plants growing in hydrocarbon- contaminated soils, a number of ACC-deaminase containing Pseudomonas strains were isolated and shown to possess a variety of growth-promoting characteristics [49]. In addition an ACC-containing strain of Pseudomonas fluorescens stimulated plant growth and promoted heavy metal uptake in rape [41].

Since ACC deaminase positive Pseudomonas strains have been shown to alleviate salinity stress, and our Pseudomonas isolates (Table 6) are from plants growing in high saline environments on the Oregon coast, these isolates are good candidates for improving growth and salt stress tolerance in other forage and turf grasses, as well as other crop species. The ACC-deaminase positive Pseudomonas isolates $\mathrm{B}$ and $\mathrm{H}$ are of particular interest, since they were found in multiple plant genera, indicating their ability to infect different plant species. They were also found in more than one location, which may mean that they are more common in Oregon (Table 5).

There are a great number of different bacteria species from a large number of genera that possess ACC deaminase activity [8] [9] [23] [49] [62] [86]. In our analysis, we found four other genera in addition to Pseudomonas that possessed ACC deaminase activity. However, they are not as well characterized for their growth and stress tolerance enhancing capabilities. In the genus Achromobacter, the endophytic bacterium Achromobacter xylosoxidans was shown to promote growth in wheat [87]. The endophytic bacterium Achromobacter xylosoxidans, was also shown to improve phytoremediation of phenolic pollutants in Arabidopsis and in vetiver grass [46] [47]. A different strain of Achromobacter xylosoxidans increased growth and resistance to blast fungus in rice [88]. Most relevant to our study, the plant-growth-promoting bacteria ACC deaminase containing Achromobacter piechaudii was shown to improve growth of tomato and pepper when subjected to drought [89], and also improved the growth of tomato when subjected to salt stress [90]. This demonstrated that the same ACC-deaminase-containing bacteria has the potential to improve tolerance to more than one type of stress. There also have been a number of endophytic Rhodococcus strains that have been identified to possess ACC deaminase activity and other common attributes associated with plant growth promoting bacteria [23] [49], however they have not been extensively study for their potential to improve plant growth under stress. Interestingly, the first report of Rhizobium strains containing ACC deaminase activity resulted from an examination of 13 Rhizobium strains that were capable of nodulating different legumes [91]. There were also 27 Rhizobium strains having ACC deaminase activity identified from a survey of 233 Rhizobia strains collected from sites across Canada [86]. To our knowledge, our study is the first report of ACC deaminase activity reported in the genus Altererythrobacter.

In our study, we found over 36 different taxonomic groups of endophytic 
bacteria, of which only five taxa contained strains that possessed ACC deaminase activity. Of the remaining bacterial isolates, some may not normally exist as endophytes, but may have been opportunistic in gaining access to the interior of the plant as a result of damage to the plants exterior surfaces. After gaining access these bacteria may have migrated to other locations within the plant. Some of the bacteria may be pathogens that infect the surface as well as the interior of the plant. Some may be benign symbionts, which provide no real benefit to their host. In addition to the ACC deaminase containing bacterial strains identified in this study, there most likely are other bacteria in our collection that are providing benefits to the host plant in this austere and harsh environment. Bacillus is one of the genera that may yield potential beneficial endophytes. While there have been Bacillus strains displaying ACC deaminase activity [23] [49] [92], in our survey none of the ten Bacillus isolates tested positive for ACC deaminase activity. However Bacillus species have been shown to improve growth in plants in other ways, such as through the release of volatile compounds [93] [94], the activation of signaling pathways [52], or the production and manipulation of phytohormones [34] [95]. Furthermore, a number of different strains of Bacillus have been shown to be good biological control agents against pathogens [50] [52] [96] [97]. Recently it was shown that, when introduced into Brachypodium distachyon, an endophytic strain of Bacillus subtilis improved growth and alleviated the effects of drought stress [98]. Another interesting aspect to this study was how efficiently it colonized the plant. The bacterium was able to spread systemically throughout the plant, establish itself in the roots, aerial plant tissues and organs, and was vertically transmitted to seeds.

The long-term utility of a beneficial organism in an agricultural setting depends on the ease of establishing the microorganism's association with the target plant, its persistence under different environmental conditions, and the length of time the organism will be able to provide a benefit to the plant. The benefit of utilizing an endophyte over a soil-based bacterium is that an endophyte is already established in the plant, and if seed-borne it can be maintained, and provide continued benefits to the next generation with no additional inputs. Endophyte infected plants require less inputs since they are already in the plant or seed. However, when using soil-based bacterium, pretreatment of soil, seed or seedlings would be necessary prior to planting. In an agricultural setting endophytes provide benefits directly to the host plant, whereas soil associated bacteria could also have the potential to improve the growth of weeds in the field. Furthermore, endophytic bacteria would be less prone to effects of soil composition, competition from other microorganisms present in the soil, and environmental effects that cause changes to the composition and dynamics of the microbiome where the crop is being grown, than their rhizospheric counterparts.

\section{Conclusion}

Grasses are a critical component for livestock production and maintaining the food supply. Grasses also provide feedstock for bioenergy, erosion control, habi- 
tat for biologically diverse animals, buffers for watersheds, sinks for carbon sequestration and valuable landscape/recreational surfaces. As water resources diminish throughout the US and worldwide due to overuse and climate change, innovative approaches such as the discovery, development, and utilization of novel endophytes will be necessary to improve water stress tolerance in grasslands and other crop species. The purpose of this study was to identify new bacterial endophytes that exist in Oregon that could potentially improve grass stress tolerance without using direct genetic modification, and without introducing foreign or exotic species into this diverse agricultural production area. Our future research will be directed at investigating the ability of the ACC deaminase positive isolates identified in this study to improve growth in grass species and crop plants when subjected to salt and drought stress. In addition, since endophytic bacteria can utilize other mechanisms to improve growth, research will also focus on investigating the ACC deaminase positive isolates and other selected isolates for phytohormone production, bioactive compounds, phosphate solubilization, nitrogen fixation, as well as their utility as biocontrol agents against pathogens. The discovery and utilization of bacterial endophytes as a biological resource have the potential to improve yield and persistence, as well as increase the adaptability of grasses and other crops grown in diverse environments and to meet the challenges associated with an unpredictable climate.

\section{Acknowledgements}

Special thanks is extended to Dr. Richard Halse at Oregon State University for his help in identification of collected grasses, to the Oregon Parks and Recreation Department for issuing the permit to allow for the collection of plants along the Oregon Coast, Dr. Rachel Okrent USDA-ARS Corvallis Oregon, for her input on primers used to amplify ITS region and Dr. Qianli An Institute of Biotechnology, Zhejiang University, Hangzhou, China for his assistance with the ACC deaminase activity assay. Experimental methods performed in this research complied with current laws and regulations of the USA. Mention of trademark, vendor, or corporation names in this publication is for the information and convenience of the reader. Such use does not constitute an official endorsement or approval by the United States Department of Agriculture or the Agricultural Research Service of any product or service to the exclusion of others that may be suitable.

\section{References}

[1] Koehler, A. (2008) Water Use in LCA: Managing the Planet's Freshwater Resources. The International Journal of Life Cycle Assessment, 13, 451-455. https://doi.org/10.1007/s11367-008-0028-6

[2] Yeo, A.R. (1999) Predicting the Interaction between the Effects of Salinity and Climate Change on Crop Plants. Scientia Horticulturae, 78, 159-174. https://doi.org/10.1016/S0304-4238(98)00193-9

[3] Pitman, M.G. and Läuchli, A. (2002) Global Impact of Salinity and Agricultural Ecosystems. In: Läuchli, A. and Lüttge, U., Eds., Salinity: Environment-Plants- 
Molecules, Springer, Berlin, 3-20.

[4] Munns, R. (2005) Genes and Salt Tolerance: Bringing Them Together. New Phytologist, 167, 645-663. https://doi.org/10.1111/j.1469-8137.2005.01487.x

[5] Vinocur, B. and Altman, A. (2005) Recent Advances in Engineering Plant Tolerance to Abiotic Stress: Achievements and Limitations. Current Opinion in Biotechnology, 16, 123-132. https://doi.org/10.1016/j.copbio.2005.02.001

[6] Roy, S.J., Negrão, S. and Tester, M. (2014) Salt Resistant Crop Plants. Current Opinion in Biotechnology, 26, 115-124. https://doi.org/10.1016/j.copbio.2013.12.004

[7] Hanjra, M.A. and Qureshi, M.E. (2010) Global Water Crisis and Future Food Security in an Era of Climate Change. Food Policy, 35, 365-377. https://doi.org/10.1016/j.foodpol.2010.05.006

[8] Grover, M., Ali, S.Z., Sandhya, V., Rasul, A. and Venkateswarlu, B. (2011) Role of Microorganisms in Adaptation of Agriculture Crops to Abiotic Stresses. World Journal of Microbiology and Biotechnology, 27, 1231-1240. https://doi.org/10.1007/s11274-010-0572-7

[9] Ahemad, M. and Kibret, M. (2014) Mechanisms and Applications of Plant Growth Promoting Rhizobacteria: Current Perspective. Journal of King Saud University-Science, 26, 1-20. https://doi.org/10.1016/j.jksus.2013.05.001

[10] Hardoim, P.R., van Overbeek, L.S., Berg, G., Pirttilä, A.M., Compant, S., Campisano, A., Döring, M. and Sessitsch, A. (2015) The Hidden World within Plants: Ecological and Evolutionary Considerations for Defining Functioning of Microbial Endophytes. Microbiology and Molecular Biology Reviews, 79, 293-320. https://doi.org/10.1128/MMBR.00050-14

[11] Brewin, N.J. (1991) Development of the Legume Root Nodule. Annual Review of Cell Biology, 7,191-226. https://doi.org/10.1146/annurev.cb.07.110191.001203

[12] Markmann, K. and Parniske, M. (2009) Evolution of Root Endosymbiosis with Bacteria: How Novel are Nodules? Trends in Plant Science, 14, 77-86. https://doi.org/10.1016/j.tplants.2008.11.009

[13] Brewin, N.J. (2010) Root Nodules (Legume-Rhizobium Symbiosis). John Wiley \& Sons Ltd., Chichester.

[14] Horner-Devine, M.C., Carney, K.M. and Bohannan, B.J. (2004) An Ecological Perspective on Bacterial Biodiversity. Proceedings of the Royal Society of London B: Biological Sciences, 271, 113-122. https://doi.org/10.1098/rspb.2003.2549

[15] Rosenblueth, M. and Martínez-Romero, E. (2006) Bacterial Endophytes and Their Interactions with Hosts. Molecular Plant-Microbe Interactions, 19, 827-837. https://doi.org/10.1094/MPMI-19-0827

[16] Bacon, C.W. and Hinton, D.M. (2007) Bacterial Endophytes: The Endophytic Niche, Its Occupants, and Its Utility. In: Gnanamanickam, S.S., Ed., Plant-Associated Bacteria, Springer, Dordrecht, 155-194.

[17] Zinniel, D.K., Lambrecht, P., Harris, N.B., Feng, Z., Kuczmarski, D., Higley, P., Ishimaru, C.A., Arunakumari, A., Barletta, R.G. and Vidaver, A.K. (2002) Isolation and Characterization of Endophytic Colonizing Bacteria from Agronomic Crops and Prairie Plants. Applied and Environmental Microbiology, 68, 2198-2208. https://doi.org/10.1128/AEM.68.5.2198-2208.2002

[18] Hallmann, J., Quadt-Hallmann, A., Mahaffee, W.F. and Kloepper, J.W. (1997) Bacterial Endophytes in Agricultural Crops. Canadian Journal of Microbiology, 43, 895-914. https://doi.org/10.1139/m97-131

[19] Sturz, A.V., Christie, B.R., Matheson, B.G. and Nowak, J. (1997) Biodiversity of Endophytic Bacteria which Colonize Red Clover Nodules, Roots, Stems and Foliage 
and Their Influence on Host Growth. Biology and Fertility of Soils, 25, 13-19. https://doi.org/10.1007/s003740050273

[20] Sturz, A.V., Christie, B.R. and Nowak, J. (2000) Bacterial Endophytes: Potential Role in Developing Sustainable Systems of Crop Production. Critical Reviews in Plant Sciences, 19, 1-30. https://doi.org/10.1016/S0735-2689(01)80001-0

[21] Glick, B.R., Cheng, Z., Czarny, J. and Duan, J. (2007) Promotion of Plant Growth by ACC Deaminase-Producing Soil Bacteria. European Journal of Plant Pathology, 119, 329-339. https://doi.org/10.1007/s10658-007-9162-4

[22] Ryan, R.P., Germaine, K., Franks, A., Ryan, D.J. and Dowling, D.N. (2008) Bacterial Endophytes: Recent Developments and Applications. FEMS Microbiology Letters, 278, 1-9. https://doi.org/10.1111/j.1574-6968.2007.00918.x

[23] Rashid, S., Charles, T.C. and Glick, B.R. (2012) Isolation and Characterization of New Plant Growth-Promoting Bacterial Endophytes. Applied Soil Ecology, 61, 217-224. https://doi.org/10.1016/j.apsoil.2011.09.011

[24] Glick, B.R., Patten, C.L., Holguin, G. and Penrose, D.M. (1999) Biochemical and Genetic Mechanisms Used by Plant Growth Promoting Bacteria. Imperial College Press, London. https://doi.org/10.1142/p130

[25] Glick, B.R. (2014) Bacteria with ACC Deaminase Can Promote Plant Growth and Help to Feed the World. Microbiological Research, 169, 30-39.

https://doi.org/10.1016/j.micres.2013.09.009

[26] Reinhold-Hurek, B. and Hurek, T. (1998). Life in Grasses: Diazotrophic Endophytes. Trends in Microbiology, 6, 139-144. https://doi.org/10.1016/S0966-842X(98)01229-3

[27] James, E.K. (2000) Nitrogen Fixation in Endophytic and Associative Symbiosis. Field Crops Research, 65, 197-209. https://doi.org/10.1016/S0378-4290(99)00087-8

[28] Cocking, E.C. (2003) Endophytic Colonization of Plant Roots by Nitrogen-Fixing Bacteria. Plant and Soil, 252, 169-175. https://doi.org/10.1023/A:1024106605806

[29] Dalton, D.A., Kramer, S., Azios, N., Fusaro, S., Cahill, E. and Kennedy, C. (2004) Endophytic Nitrogen Fixation in Dune Grasses (Ammophila arenaria and Elymus mollis) from Oregon. FEMS Microbiology Ecology, 49, 469-479.

https://doi.org/10.1016/j.femsec.2004.04.010

[30] Franche, C., Lindström, K. and Elmerich, C. (2009) Nitrogen-Fixing Bacteria Associated with Leguminous and Non-Leguminous Plants. Plant and Soil, 321, 35-59. https://doi.org/10.1007/s11104-008-9833-8

[31] Rodríguez, H. and Fraga, R. (1999) Phosphate Solubilizing Bacteria and Their Role in Plant Growth Promotion. Biotechnology Advances, 17, 319-339. https://doi.org/10.1016/S0734-9750(99)00014-2

[32] Patten, C.L. and Glick, B.R. (1996) Bacterial Biosynthesis of Indole-3-Acetic Acid. Canadian Journal of Microbiology, 42, 207-220. https://doi.org/10.1139/m96-032

[33] Spaepen, S., Vanderleyden, J. and Remans, R. (2007) Indole-3-Acetic Acid in Microbial and Microorganism-Plant Signaling. FEMS Microbiology Reviews, 31, 425-448. https://doi.org/10.1111/j.1574-6976.2007.00072.x

[34] Ortíz-Castro, R., Valencia-Cantero, E. and López-Bucio, J. (2008) Plant Growth Promotion by Bacillus megaterium Involves Cytokinin Signaling. Plant Signaling and Behavior, 3, 263-265. https://doi.org/10.4161/psb.3.4.5204

[35] Vadassery, J., Ritter, C., Venus, Y., Camehl, I., Varma, A., Shahollari, B., Novak, O., Strnad, M., Ludwig-Mueller, J. and Oelmueller, R. (2008) The Role of Auxins And Cytokinins in the Mutualistic Interaction Between Arabidopsis and Piriformosporaindica. Molecular Plant-Microbe Interactions, 21, 1371-1383. 
https://doi.org/10.1094/MPMI-21-10-1371

[36] Cohen, A.C., Travaglia, C.N., Bottini, R. and Piccoli, P.N. (2009) Participation of Abscisic Acid and Gibberellins Produced by Endophytic Azospirillum in the Alleviation of Drought Effects in Maize. Botany, 87, 455-462.

https://doi.org/10.1139/B09-023

[37] Khan, A.L., Waqas, M., Kang, S.M., Al-Harrasi, A., Hussain, J., Al-Rawahi, A., Al-Khiziri, S., Ullah, I., Ali, L., Jung, H.Y. and Lee, I.J. (2014) Bacterial EndophyteSphingomonas sp. LK11 Produces Gibberellins and IAA and Promotes Tomato Plant Growth. Journal of Microbiology, 52, 689-695. https://doi.org/10.1007/s12275-014-4002-7

[38] Morgan, P.W. and Drew, M.C. (1997) Ethylene and Plant Responses to Stress. Physiologia Plantarum, 100, 620-630. https://doi.org/10.1111/j.1399-3054.1997.tb03068.x

[39] Wang, F., Cui, X., Sun, Y. and Dong, C.H. (2013) Ethylene Signaling and Regulation in Plant Growth and Stress Responses. Plant Cell Reports, 32, 1099-1109 https://doi.org/10.1007/s00299-013-1421-6

[40] Glick, B.R. (2005) Modulation of Plant Ethylene Levels by the Enzyme ACC Deaminase. FEMS Microbiology Letters, 251, 1-7. https://doi.org/10.1016/j.femsle.2005.07.030

[41] Sheng, X.F., Xia, J. J., Jiang, C.Y., He, L.Y. and Qian, M. (2008) Characterization of Heavy Metal-Resistant Endophytic Bacteria from Rape (Brassica napus) Roots and Their Potential in Promoting the Growth and Lead Accumulation of Rape. Environmental Pollution, 156, 1164-1170. https://doi.org/10.1016/j.envpol.2008.04.007

[42] Rajkumar, M., Ae, N. and Freitas, H. (2009) Endophytic Bacteria and Their Potential to Enhance Heavy Metal Phytoextraction. Chemosphere, 77, 153-160. https://doi.org/10.1016/j.chemosphere.2009.06.047

[43] Weyens, N., van der Lelie, D., Taghavi, S. and Vangronsveld, J. (2009) Phytoremediation: Plant-Endophyte Partnerships Take the Challenge. Current Opinion in Biotechnology, 20, 248-254. https://doi.org/10.1016/j.copbio.2009.02.012

[44] Sun, L.N., Zhang, Y.F., He, L.Y., Chen, Z.J., Wang, Q.Y., Qian, M. and Sheng, X.F. (2010) Genetic Diversity and Characterization of Heavy Metal-Resistant-Endophytic Bacteria from Two Copper-Tolerant Plant Species on Copper Mine Wasteland. Bioresource Technology, 101, 501-509.

https://doi.org/10.1016/j.biortech.2009.08.011

[45] Luo, S.L., Chen, L., Chen, J.L., Xiao, X., Xu, T.Y., Wan, Y., Rao, C., Liu, C.B., Liu, Y.T., Lai, C. and Zeng, G.M. (2011) Analysis and Characterization of Cultivable Heavy Metal-Resistant Bacterial Endophytes Isolated from Cd-Hyperaccumulator Solanumnigrum L. and Their Potential Use for Phytoremediation. Chemosphere, 85, 1130-1138. https://doi.org/10.1016/j.chemosphere.2011.07.053

[46] Ho, Y.N., Mathew, D.C., Hsiao, S.C., Shih, C.H., Chien, M.F., Chiang, H.M. and Huang, C.C. (2012) Selection and Application of Endophytic Bacterium Achromobacterxylosoxidans Strain F3B for Improving Phytoremediation of Phenolic Pollutants. Journal of Hazardous Materials, 219, 43-49. https://doi.org/10.1016/j.jhazmat.2012.03.035

[47] Ho, Y.N., Hsieh, J.L. and Huang, C.C. (2013) Construction of a Plant-Microbe Phytoremediation System: Combination of Vetiver Grass with a Functional Endophytic Bacterium, Achromobacter xylosoxidans F3B, for Aromatic Pollutants Removal. Bioresource Technology, 145, 43-47. https://doi.org/10.1016/j.biortech.2013.02.051

[48] Afzal, M., Khan, Q.M. and Sessitsch, A. (2014) Endophytic Bacteria: Prospects and 
Applications for the Phytoremediation of Organic Pollutants. Chemosphere, 117, 232-242. https://doi.org/10.1016/j.chemosphere.2014.06.078

[49] Kukla, M., Płociniczak, T. and Piotrowska-Seget, Z. (2014) Diversity of Endophytic Bacteria in Lolium perenne and Their Potential to Degrade Petroleum Hydrocarbons and Promote Plant Growth. Chemosphere, 117, 40-46. https://doi.org/10.1016/j.chemosphere.2014.05.055

[50] Bacon, C.W. and Hinton, D.M. (2002) Endophytic and Biological Control Potential of Bacillus mojavensis and Related Species. Biological Control, 23, 274-284. https://doi.org/10.1006/bcon.2001.1016

[51] Compant, S., Duffy, B., Nowak, J., Clément, C. and Barka, E.A. (2005) Use of Plant Growth-Promoting Bacteria for Biocontrolof Plant Diseases: Principles, Mechanisms of Action, and Future Prospects. Applied and Environmental Microbiology, 71, 4951-4959. https://doi.org/10.1128/AEM.71.9.4951-4959.2005

[52] Kloepper, J.W., Ryu, C.M. and Zhang, S. (2004) Induced Systemic Resistance and Promotion of Plant Growth by Bacillus Spp. Phytopathology, 94, 1259-1266. https://doi.org/10.1094/PHYTO.2004.94.11.1259

[53] Berg, G. and Hallmann, J. (2006) Control of Plant Pathogenic Fungi with Bacterial Endophytes. In: Schulz, B.J.E., Boyle, C.J.C. and Sieber, T.N., Eds., Microbial Root Endophytes, Springer, Berlin, 53-69. https://doi.org/10.1007/3-540-33526-9_4

[54] Kloepper, J.W. and Ryu, C.M. (2006) Bacterial Endophytes as Elicitors of Induced Systemic Resistance. In: Schulz, B.J.E., Boyle, C.J.C. and Sieber, T.N., Eds., Microbial Root Endophytes, Springer, Berlin, 33-52.

https://doi.org/10.1007/3-540-33526-9_3

[55] Mercado-Blanco, J. and Bakker, P.A. (2007) Interactions between Plants and Beneficial Pseudomonas spp.: Exploiting Bacterial Traits for Crop Protection. Antonie van Leeuwenhoek, 92, 367-389. https://doi.org/10.1007/s10482-007-9167-1

[56] Yu, H., Zhang, L., Li, L., Zheng, C., Guo, L., Li, W., Sun, P. and Qin, L. (2010) Recent Developments and Future Prospects of Antimicrobial Metabolites Produced by Endophytes. Microbiological Research, 165, 437-449.

https://doi.org/10.1016/j.micres.2009.11.009

[57] Strobel, G. and Daisy, B. (2003) Bioprospecting for Microbial Endophytes and Their Natural Products. Microbiology and Molecular Biology Reviews, 67, 491-502. https://doi.org/10.1128/MMBR.67.4.491-502.2003

[58] Owen, N.L. and Hundley, N. (2004) Endophytes - The Chemical Synthesizers inside Plants. Science Progress, 87, 79-99. https://doi.org/10.3184/003685004783238553

[59] Brader, G., Compant, S., Mitter, B., Trognitz, F. and Sessitsch, A. (2014) Metabolic Potential of Endophytic Bacteria. Current Opinion in Biotechnology, 27, 30-37. https://doi.org/10.1016/j.copbio.2013.09.012

[60] Puente, M.E., Li, C.Y. and Bashan, Y. (2009) Endophytic Bacteria in Cacti Seeds Can Improve the Development of Cactus Seedlings. Environmental and Experimental Botany, 66, 402-408. https://doi.org/10.1016/j.envexpbot.2009.04.007

[61] Siddikee, M.A., Chauhan, P.S., Anandham, R., Han, G.H. and Sa, T. (2010) Isolation, Characterization, and Use for Plant Growth Promotion Under Salt Stress, of ACC Deaminase-Producing Halotolerant Bacteria Derived from Coastal Soil. Journal of Microbiology and Biotechnology, 20, 1577-1584.

https://doi.org/10.4014/jmb.1007.07011

[62] Ramadoss, D., Lakkineni, V.K., Bose, P., Ali, S. and Annapurna, K. (2013) Mitigation of Salt Stress in Wheat Seedlings by Halotolerant Bacteria Isolated from Saline Habitats. SpringerPlus, 2, 6. https://doi.org/10.1186/2193-1801-2-6 
[63] Nissinen, R.M., Mannisto, M.K. and van Elsas, J.D. (2012) Endophytic Bacterial Communities in Three Arctic Plants from Low Arctic Fell Tundra are Cold Adapted and Host-Plant Specific. FEMS Microbiology Ecology, 82, 510-522. https://doi.org/10.1111/j.1574-6941.2012.01464.X

[64] Lumactud, R., Shen, S.Y., Lau, M. and Fulthorpe, R. (2016) Bacterial Endophytes Isolated from Plants in Natural Oil Seep Soils with Chronic Hydrocarbon Contamination. Frontiers in Microbiology, 7, 755. https://doi.org/10.3389/fmicb.2016.00755

[65] Mano, H. and Morisaki, H. (2008) Endophytic Bacteria in the Rice Plant. Microbes and Environments, 23, 109-117. https://doi.org/10.1264/jsme2.23.109

[66] Gagne-Bourgue, F., Aliferis, K.A., Seguin, P., Rani, M., Samson, R. and Jabaji, S. (2013) Isolation and Characterization of Indigenous Endophytic Bacteria Associated with Leaves of Switchgrass (Panicum virgatum L.) Cultivars. Journal of Applied Microbiology, 114, 836-853. https://doi.org/10.1111/jam.12088

[67] Martin, R.C. and Dombrowski, J.E. (2015) Isolation and Identification of Fungal Endophytes from Grasses along the Oregon Coast. American Journal of Plant Sciences, 6, 3216-3230. https://doi.org/10.4236/ajps.2015.619313

[68] James, G. (2010) Universal Bacterial Identification by PCR and DNA Sequencing of 16S rRNA Gene. In: Schuller, M., Sloots, P.T., James, S.G., Halliday, L.C. and Carter, W.J.I., Eds., PCR for Clinical Microbiology, Springer, Dordrecht, 209-214. https://doi.org/10.1007/978-90-481-9039-3_28

[69] Klindworth, A., Pruesse, E., Schweer, T., Peplies, J., Quast, C., Horn, M. and Glöckner, F.O. (2012) Evaluation of General 16S Ribosomal RNA Gene PCR Primers for Classical and Next-Generation Sequencing-Based Diversity Studies. Nucleic Acids Research, 41, e1. https://doi.org/10.1093/nar/gks808

[70] Li, Z., Chang, S., Lin, L., Li, Y. and An, Q. (2011) A colorimetric Assay of 1-Aminocyclopropane-1-Carboxylate (ACC) Based on Ninhydrin Reaction for Rapid Screening of Bacteria Containing ACC Deaminase. Letters in Applied Microbiology, 53, 178-185. https://doi.org/10.1111/j.1472-765X.2011.03088.x

[71] Li, Z., Chang, S., Ye, S., Chen, M., Lin, L., Li, Y., Li, S. and An, Q. (2015) Differentiation of 1-Aminocyclopropane-1-Carboxylate (ACC) Deaminase from Its Homologs Is the Key for Identifying Bacteria Containing ACC Deaminase. FEMS Microbiology Ecology, 91, fiv112. https://doi.org/10.1093/femsec/fiv112

[72] Ulrich, K., Ulrich, A. and Ewald, D. (2008) Diversity of Endophytic Bacterial Communities in Poplar Grown Under Field Conditions. FEMS Microbiology Ecology, 63, 169-180. https://doi.org/10.1111/j.1574-6941.2007.00419.x

[73] Hardoim, P.R., van Overbeek, L.S. and van Elsas, J.D. (2008) Properties of Bacterial Endophytes and Their Proposed Role in Plant Growth. Trends in Microbiology, 16, 463-471. https://doi.org/10.1016/j.tim.2008.07.008

[74] Compant, S., Clement, C. and Sessitsch, A. (2010) Plant Growth-Promoting Bacteria in the Rhizo- and Endosphere of Plants: Their Role, Colonization, Mechanism Involved and Prospects for Utilization. Soil Biology and Biochemistry, 42, 669-678. https://doi.org/10.1016/j.soilbio.2009.11.024

[75] Janda, J.M. and Abbott, S.L. (2007) 16S rRNA Gene Sequencing for Bacterial Identification in the Diagnostic Laboratory: Pluses, Perils, and Pitfalls. Journal of Clinical Microbiology, 45, 2761-2764. https://doi.org/10.1128/JCM.01228-07

[76] Saravanakumar, D. and Samiyappan, R. (2007) ACC Deaminase from Pseudomonas fluorescens Mediated Saline Resistance in Groundnut (Arachis hypogea) Plants. Journal of Applied Microbiology, 102, 1283-1292. https://doi.org/10.1111/j.1365-2672.2006.03179.x 
[77] Zahir, Z.A., Ghani, U., Naveed, M., Nadeem, S.M. and Asghar, H.N. (2009) Comparative Effectiveness of Pseudomonas and Serratia sp. Containing ACC-Deaminase for Improving Growth and Yield of Wheat (Triticum aestivum L.) Under Salt-stressed Conditions. Archives of Microbiology, 191, 415-424. https://doi.org/10.1007/s00203-009-0466-y

[78] Jalili, F., Khavazi, K., Pazira, E., Nejati, A., Rahmani, H.A., Sadaghiani, H.R. and Miransari, M. (2009) Isolation and Characterization of ACC Deaminase-Producing Fluorescent Pseudomonads, to Alleviate Salinity Stress on Canola (Brassica napus L.) Growth. Journal of Plant Physiology, 166, 667-674. https://doi.org/10.1016/j.jplph.2008.08.004

[79] Nadeem, S.M., Zahir, Z.A., Naveed, M. and Arshad, M. (2007) Preliminary Investigations on Inducing Salt Tolerance in Maize Through Inoculation with Rhizobacteria Containing ACC Deaminase Activity. Canadian Journal of Microbiology, 53, 1141-1149. https://doi.org/10.1139/W07-081

[80] Ahmad, M., Zahir, Z.A., Asghar, H.N. and Asghar, M. (2011). Inducing Salt Tolerance in Mung Bean through Coinoculation with Rhizobia and Plant-Growth- Promoting Rhizobacteria Containing 1-Aminocyclopropane-1-Carboxylate Deaminase. Canadian Journal of Microbiology, 57, 578-589. https://doi.org/10.1139/w11-044

[81] Nadeem, S.M., Zahir, Z.A., Naveed, M., Asghar, H.N. and Arshad, M. (2010) Rhizobacteria Capable of Producing ACC-Deaminase May Mitigate Salt Stress in Wheat. Soil Science Society of America Journal, 74, 533-542. https://doi.org/10.2136/sssaj2008.0240

[82] Sadrnia, M., Maksimava, N., Khromsova, E., Stanislavich, S., Owilia, P. and Arjomandzadegan, M. (2011) Study the Effect of Bacterial 1-Aminocyclopropane-1Carboxylate Deaminase (ACC Deaminase) on Resistance to Salt Stress in Tomato Plants. Annals of University of Oradea, 18, 120-123.

[83] Ali, S., Charles, T.C. and Glick, B.R. (2014) Amelioration of High Salinity Stress Damage by Plant Growth-Promoting Bacterial Endophytes That Contain ACC Deaminase. Plant Physiology and Biochemistry, 80, 160-167.

https://doi.org/10.1016/j.plaphy.2014.04.003

[84] Haas, D. and Keel, C. (2003) Regulation of Antibiotic Production in Root-Colonizing Pseudomonas spp. and Relevance for Biological Control of Plant Disease. Annual Review of Phytopathology, 41, 117-153. https://doi.org/10.1146/annurev.phyto.41.052002.095656

[85] Ganeshan, G. and Manoj Kumar, A. (2005) Pseudomonas fluorescens, a Potential Bacterial Antagonist to Control Plant Diseases. Journal of Plant Interactions, 1, 123-134. https://doi.org/10.1080/17429140600907043

[86] Duan, J., Müller, K.M., Charles, T.C., Vesely, S. and Glick, B.R. (2009) 1-Aminocyclopropane-1-Carboxylate (ACC) Deaminase Genes in Rhizobia from Southern Saskatchewan. Microbial Ecology, 57, 423-436.

https://doi.org/10.1007/s00248-008-9407-6

[87] Jha, P. and Kumar, A. (2009) Characterization of Novel Plant Growth Promoting Endophytic Bacterium Achromobacterxylosoxidans from Wheat Plant. Microbial Ecology, 58, 179-188. https://doi.org/10.1007/s00248-009-9485-0

[88] Joe, M.M., Islam, M.R., Karthikeyan, B., Bradeepa, K., Sivakumaar, P.K. and Sa, T. (2012) Resistance Responses of Rice to Rice Blast Fungus after Seed Treatment with the Endophytic Achromobacter xylosoxidans AUM54 Strains. Crop Protection, 42, 141-148. https://doi.org/10.1016/j.cropro.2012.07.006

[89] Mayak, S., Tirosh, T. and Glick, B.R. (2004) Plant Growth-Promoting Bacteria That Confer Resistance to Water Stress in Tomatoes and Peppers. Plant Science, 166, 
525-530. https://doi.org/10.1016/j.plantsci.2003.10.025

[90] Mayak, S., Tirosh, T. and Glick, B.R. (2004) Plant Growth-Promoting Bacteria Confer Resistance in Tomato Plants to Salt Stress. Plant Physiology and Biochemistry, 42, 565-572. https://doi.org/10.1016/j.plaphy.2004.05.009

[91] Ma, W., Sebestianova, S.B., Sebestian, J., Burd, G.I., Guinel, F.C. and Glick, B.R. (2003) Prevalence of 1-Aminocyclopropane-1-Carboxylate Deaminase in Rhizobium spp. Antonie Van Leeuwenhoek, 83, 285-291. https://doi.org/10.1023/A:1023360919140

[92] Ghosh, S., Penterman, J.N., Little, R.D., Chavez, R. and Glick, B.R. (2003) Three Newly Isolated Plant Growth-Promoting Bacilli Facilitate the Seedling Growth of Canola, Brassica campestris. Plant Physiology and Biochemistry, 41, 277-281. https://doi.org/10.1016/S0981-9428(03)00019-6

[93] Zhang, H., Kim, M.S., Sun, Y., Dowd, S.E., Shi, H. and Paré, P.W. (2008) Soil Bacteria Confer Plant Salt Tolerance by Tissue-Specific Regulation of the Sodium Transporter HKT1. Molecular Plant-Microbe Interactions, 21, 737-744. https://doi.org/10.1094/MPMI-21-6-0737

[94] Zou, C., Li, Z. and Yu, D. (2010) Bacillus megaterium Strain XTBG34 Promotes Plant Growth by Producing 2-Pentylfuran. Journal of Microbiology, 48, 460-466. https://doi.org/10.1007/s12275-010-0068-Z

[95] Shahzad, R., Waqas, M., Khan, A.L., Asaf, S., Khan, M.A., Kang, S.M., Yun, B.W. and Lee, I.J. (2016) Seed-Borne Endophytic Bacillus amyloliquefaciens RWL-1 Produces Gibberellins and Regulates Endogenous Phytohormones of Oryza sativa. Plant Physiology and Biochemistry, 106, 236-243. https://doi.org/10.1016/j.plaphy.2016.05.006

[96] Melnick, R.L., Zidack, N.K., Bailey, B.A., Maximova, S.N., Guiltinan, M. and Backman, P.A. (2008) Bacterial Endophytes: Bacillus spp. from Annual Crops as Potential Biological Control Agents of Black Pod Rot of Cacao. Biological Control, 46, 46-56. https://doi.org/10.1016/j.biocontrol.2008.01.022

[97] Gond, S.K., Bergen, M.S., Torres, M.S. and White Jr., J.F. (2015) Endophytic Bacillus spp. Produce Antifungal Lipopeptides and Induce Host Defence Gene Expression in Maize. Microbiological Research, 172, 79-87. https://doi.org/10.1016/j.micres.2014.11.004

[98] Gagné-Bourque, F., Mayer, B.F., Charron, J.-B., Vali, H., Bertrand, A. and Jabaji, S. (2015) Accelerated Growth Rate and Increased Drought Stress Resilience of the Model Grass Brachypodium distachyon Colonized by Bacillus subtilis B26. PLoS ONE, 10, e0130456. https://doi.org/10.1371/journal.pone.0130456 


\section{Supplemental Tables}

Table S1. Hit descriptions of isolates.

\begin{tabular}{|c|c|c|c|c|c|c|c|c|c|}
\hline 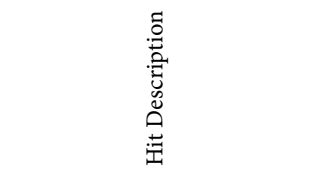 & 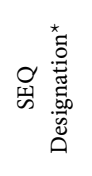 & 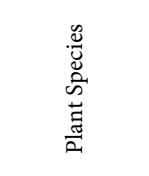 & 莺 & 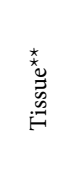 & $\begin{array}{l}\stackrel{x}{x} \\
\stackrel{x}{\leftrightarrows}\end{array}$ & 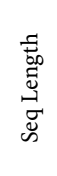 & 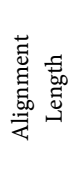 & 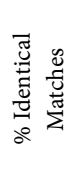 & 营 \\
\hline Achromobactersp. & A & Ammophilia & Coos Bay & RC & CB3BRC-3B & 460 & 437 & 99.54 & gi|565666205|emb|HG324052.1| \\
\hline Actinomycetales bacterium & A & Descampsia & Yachats & RC & YH4RC-3A & 460 & 436 & 98.85 & gi|222427416|dbj|AB461704.1| \\
\hline Aeromicrobium sp & A & Bromus & Bob Creek Wayside & $\mathrm{RC}$ & BS6RC-1A & 460 & 441 & 100 & gi|322162258|gb|JF176853.1| \\
\hline Agreia pratensis & A & Bromus & Harbor Vista & $\mathrm{RC}$ & HV12RC- $4 \mathrm{~A}$ & 460 & 437 & 100 & gi|342067998|gb|JF632813.1| \\
\hline Agreia pratensis strain & B & Phalaris & Harbor Vista & $\mathrm{RC}$ & HV2RC-2A & 460 & 444 & 99.77 & gi|118193424|gb|EF010578.1| \\
\hline Agreia pratensis strain & B & Bromus & Harbor Vista & s & HV12SS-1A & 460 & 436 & 100 & gi|219878321|ref|NR_025460.1| \\
\hline Agreia bicolorata strain & B & Festuca & Harbor Vista & $\mathrm{RC}$ & HV13RC- $4 \mathrm{~A}$ & 460 & 445 & 99.55 & gi|322182817|gb|JF197412.1| \\
\hline $\begin{array}{l}\text { Agrobacterium tumefaciens } \\
\text { strain }\end{array}$ & A & Bromus & Coos Bay & $\mathrm{RC}$ & CB2BRC-3A & 433 & 413 & 99.76 & gi|151303412|gb|EF620461.1| \\
\hline Alphaproteobacterium & A & Bromus & Yachats & $\mathrm{RC}$ & YH3RC-6A & 443 & 430 & 99.53 & gi|411113074|gb|JQ387405.2| \\
\hline Alphaproteobacterium & B & Agrostis & Yachats & $\mathrm{RC}$ & YH5RC-3A & 460 & 432 & 98.61 & gi|333122829|gb|JF745377.1| \\
\hline Altererythrobacter marenisis & A & Agrostis & Yachats & S & YH7SS-1A & 449 & 422 & 98.34 & gi|636632492|gb|KJ549198.1| \\
\hline Arthrobacter sp. & A & Bromus & Coos Bay & $\mathrm{RC}$ & CB2BRC-4B & 460 & 440 & 99.77 & gi|332002558|gb|JF683267.1| \\
\hline Bacillus sp. & A & Phalaris & Harbor Vista & $\mathrm{RC}$ & HV1RC-2A & 460 & 453 & 99.34 & gi|347812460|gb|HM584282.1| \\
\hline Bacillus sp. & B & Bromus & Bob Creek Wayside & $\mathrm{RC}$ & BS3RC-2A & 460 & 453 & 98.9 & gi|347812460|gb|HM584282.1| \\
\hline Bacillus simplex strain & $\mathrm{C}$ & Ammophilia & Coos Bay & $\mathrm{RC}$ & CB3ARC-1A & 460 & 441 & 100 & gi|310780859|gb|HQ432812.1| \\
\hline Bacillus safensis & $\mathrm{D}$ & Festuca & Harbor Vista & $\mathrm{L}$ & HV9LF-3A & 460 & 446 & 100 & gi|340003212|emb|FR877571.1| \\
\hline Bacillus megaterium strain & $\mathrm{E}$ & Bromus & Coos Bay & $\mathrm{L}$ & CB2BLF-3A & 460 & 447 & 99.78 & gi|449040652|gb|KC414707.1| \\
\hline Bacillus sp. & $\mathrm{F}$ & Bromus & Coos Bay & $\mathrm{L}$ & CB2BLF-1A & 460 & 452 & 99.78 & gi|347812460|gb|HM584282.1| \\
\hline Bacillus sp. & $\mathrm{F}$ & Festuca & Bob Creek Wayside & $\mathrm{RC}$ & BS5RC-13A & 460 & 451 & 99.33 & gi|347812460|gb|HM584282.1| \\
\hline Bacillus sp. & $\mathrm{F}$ & Agrostis & Yachats & RC, $\mathrm{L}$ & YH7LF-1A & 460 & 452 & 99.56 & gi|347812460|gb|HM584282.1| \\
\hline Bacillus sp. & $\mathrm{F}$ & Phalaris & Harbor Vista & RC & HV1RC-1A & 460 & 450 & 99.56 & gi|485650999|gb|KC545293.1| \\
\hline Bacillus sp. & $\mathrm{F}$ & Bromus & Harbor Vista & RC & HV5RC-1A & 460 & 449 & 99.11 & gi|485650999|gb|KC545293.1| \\
\hline $\begin{array}{c}\text { Uncultured } \\
\text { Betaproteobacteria bacterium }\end{array}$ & A & Phalaris & Yachats & s & YH6SS-1A & 460 & 445 & 99.1 & gi $238000899 \mid$ emb|CU922693.1| \\
\hline Uncultured bordetella sp. & A & Bromus & Coos Bay & RC & CB2BRC-5A & 460 & 138 & 85.51 & gi|346988245|gb|JN590663.1| \\
\hline $\begin{array}{c}\text { Brachybacterium } \\
\text { tyrofermentans strain }\end{array}$ & $\mathrm{A}$ & Festuca & Harbor Vista & $\mathrm{RC}$ & HV6RC-2A & 460 & 449 & 98 & gi|219846680|ref|NR_026272.1| \\
\hline Brevundimonas sp. & A & Bromus & Yachats & RC & YH3RC-9A & 445 & 430 & 99.3 & gi|224027500|emb|AM988991.1| \\
\hline Caryophanon sp. & A & Festuca & Harbor Vista & $\mathrm{L}$ & HV9LF-1A & 460 & 443 & 99.77 & gi|14537944|gb|AF385535.1| \\
\hline Chryseobacterium & & Descampsia & Yachats & RC & YH4RC-1A & 460 & 436 & 100 & gi|322163911|gb|JF178506.1| \\
\hline
\end{tabular}




\section{Continued}

\begin{tabular}{|c|c|c|c|c|c|c|c|c|c|}
\hline Clavibacter michiganensis & A & Bromus & Harbor Vista & S & HV8SS-1A & 460 & 437 & 100 & gi|444304176|ref|NR_074600.1| \\
\hline $\begin{array}{l}\text { Uncultured Curtobacterium } \\
\text { sp. }\end{array}$ & A & Descampsia & Yachats & S & YH4SS-2A & 460 & 449 & 99.55 & gi|545341513|gb|KF504745.1| \\
\hline $\begin{array}{l}\text { Curtobacterium } \\
\text { flaccumfaciens }\end{array}$ & B & Festuca & Coos Bay & S & CB4RCSS-1A & 460 & 442 & 97.74 & gi|602152779|emb|HG934367.1| \\
\hline $\begin{array}{c}\text { Curtobacterium } \\
\text { oceanosedimentum strain }\end{array}$ & $\mathrm{C}$ & Bromus & Yachats & $\mathrm{RC}$ & YH3RC-12A & 460 & 442 & 99.55 & gi|559795249|ref|NR_104839.1| \\
\hline $\begin{array}{l}\text { Curtobacterium } \\
\text { flaccumfaciens }\end{array}$ & $\mathrm{D}$ & Bromus & Coos Bay & $\mathrm{RC}$ & CB2BRC-2B & 460 & 440 & 100 & gi|602152779|emb|HG934367.1| \\
\hline $\begin{array}{l}\text { Curtobacterium } \\
\text { flaccumfaciens }\end{array}$ & $\mathrm{D}$ & Festuca & Coos Bay & S & CB4RCSS-3A & 460 & 442 & 99.77 & gi|602152779|emb|HG934367.1| \\
\hline $\begin{array}{l}\text { Curtobacterium } \\
\text { flaccumfaciens }\end{array}$ & $\mathrm{D}$ & Bromus & Bob Creek Wayside & RC & BS3RC-1A & 460 & 448 & 99.78 & gi|602152779|emb|HG934367.1| \\
\hline $\begin{array}{l}\text { Curtobacterium } \\
\text { flaccumfaciens }\end{array}$ & $\mathrm{D}$ & Festuca & Bob Creek Wayside & $\mathrm{RC}$ & BS5RC-1A & 460 & 440 & 100 & gi|602152779|emb|HG934367.1| \\
\hline $\begin{array}{l}\text { Curtobacterium } \\
\text { flaccumfaciens }\end{array}$ & $\mathrm{D}$ & Festuca & Bob Creek Wayside & $\mathrm{RC}, \mathrm{S}$ & BS7RC-1A & 460 & 435 & 100 & gi|602152779|emb|HG934367.1| \\
\hline $\begin{array}{l}\text { Curtobacterium } \\
\text { flaccumfaciens }\end{array}$ & $\mathrm{D}$ & Phalaris & Bob Creek Wayside & S & BS9SS-1B & 460 & 438 & 100 & gi|602152779|emb|HG934367.1| \\
\hline $\begin{array}{l}\text { Curtobacterium } \\
\text { flaccumfaciens }\end{array}$ & $\mathrm{D}$ & Festuca & Harbor Vista & S & HV14SS-2A & 460 & 450 & 99.78 & gi|602152779|emb|HG934367.1| \\
\hline $\begin{array}{l}\text { Curtobacterium } \\
\text { flaccumfaciens }\end{array}$ & $\mathrm{D}$ & Bromus & Yachats & RC & YH3RC-5A & 460 & 444 & 100 & gi|602152779|emb|HG934367.1| \\
\hline Enterobacteriaceae bacterium & A & Festuca & Bob Creek Wayside & S & BS7SS-4A & 460 & 432 & 99.77 & gi|399764347|gb|JX067714.1| \\
\hline $\begin{array}{c}\text { Exiguobacterium sibiricum } \\
\text { strain }\end{array}$ & A & Festuca & Harbor Vista & S & HV14SS-1A & 460 & 422 & 86.26 & gi|559101922|gb|KF815556.1| \\
\hline Exiguobacterium sp. & $\mathrm{B}$ & Bromus & Harbor Vista & $\mathrm{RC}$ & HV11RC-2A & 460 & 440 & 100 & gi|619856028|gb|KJ456597.1| \\
\hline Exiguobacterium undae strain & $\mathrm{C}$ & Bromus & Yachats & $\mathrm{RC}$ & YH3RC-3A & 460 & 435 & 100 & gi|545599219|gb|KF555609.1| \\
\hline Flavobacterium sp. & A & Festuca & Bob Creek Wayside & $\mathrm{RC}$ & BS8RC-2A & 460 & 441 & 99.55 & gi|189231650|emb|FM161717.1| \\
\hline Flavobacterium sp. & $\mathrm{B}$ & Bromus & Harbor Vista & S & HV11SS-1A & 460 & 439 & 99.54 & gi|224027433|emb|AM988924.1| \\
\hline Flavobacterium sp. & $\mathrm{C}$ & Phalaris & Yachats & S & YH6SS-3A & 460 & 442 & 99.32 & gi|125988135|emb|AM492721.1| \\
\hline Frigoribacterium faeni & A & Festuca & Coos Bay & S & CB4RCSS-2A & 460 & 447 & 98.66 & gi|590121420|emb|HE716910.1| \\
\hline Frigoribacterium faeni & $\mathrm{B}$ & Bromus & Bob Creek Wayside & S & BS3SS-3A & 460 & 447 & 98.66 & gi|590121420|emb|HE716910.1| \\
\hline Frigoribacterium faeni & $\mathrm{C}$ & Bromus & Yachats & RC & YH3RC-11A & 460 & 438 & 100 & gi|590121420|emb|HE716910.1| \\
\hline Kocuria marina strain & A & Phalaris & Harbor Vista & RC & HV2RC-1A & 460 & 447 & 100 & gi|572540661|gb|KF777377.1| \\
\hline Kocuria palustris & $\mathrm{B}$ & Festuca & Bob Creek Wayside & $\mathrm{RC}$ & BS5RC-12A & 460 & 447 & 99.78 & gi|590121451|emb|HE716941.1| \\
\hline Kocuria palustris & $\mathrm{C}$ & Festuca & Harbor Vista & $\mathrm{L}$ & HV6LF-1A & 460 & 442 & 98.42 & gi|296963424|gb|HM269829.1| \\
\hline Luteimonas aestuarii strain & A & Festuca & Harbor Vista & $\mathrm{RC}$ & HV4RC-3A & 460 & 440 & 99.77 & gi|583842931|gb|KF876901.1| \\
\hline Uncultured Lysobactersp. & A & Festuca & Harbor Vista & $\mathrm{RC}$ & HV14RC-3A & 460 & 450 & 99.78 & gi|307713682|gb|HM438532.1| \\
\hline Microbacteriaceae bacterium & A & Bromus & Coos Bay & RC & CB2ARC-4A & 460 & 447 & 84.79 & gi|399764363|gb|JX067730.1| \\
\hline Microbacterium sp. & B & Hordeum & Coos Bay & S & CB5SS-3A & 460 & 448 & 97.99 & gi|341867097|gb|JN196543.1| \\
\hline Microbacteriaceae bacterium & $\mathrm{C}$ & Bromus & Coos Bay & $\mathrm{L}$ & CB2ALF-1A & 460 & 442 & 95.48 & gi|383850150|gb|JQ229710.1| \\
\hline
\end{tabular}




\section{Continued}

\begin{tabular}{|c|c|c|c|c|c|c|c|c|c|}
\hline Microbacterium sp. & $\mathrm{D}$ & Festuca & Harbor Vista & $\mathrm{RC}$ & HV4RC-1A & 460 & 444 & 99.32 & gi|341867097|gb|JN196543.1| \\
\hline Uncultured bacterium & $\mathrm{E}$ & Descampsia & Yachats & $\mathrm{RC}$ & YH4RC-4A & 460 & 438 & 100 & gi|322199775|gb|JF214370.1| \\
\hline Microbacteriaceae bacterium & $\mathrm{F}$ & Bromus & Coos Bay & $\mathrm{RC}$ & CB2BRC-6A & 460 & 446 & 99.55 & gi|399764363|gb|JX067730.1| \\
\hline Microbacteriaceae bacterium & $\mathrm{F}$ & Descampsia & Yachats & $S$ & YH4SS-3A & 460 & 448 & 99.55 & gi|399764363|gb|JX067730.1| \\
\hline Microbacterium sp. & G & Ammophila & Harbor Vista & $\mathrm{L}$ & HV7LF-1A & 460 & 451 & 99.33 & gi|341867097|gb|JN196543.1| \\
\hline Microbacterium sp. & $\mathrm{H}$ & Phalaris & Bob Creek Wayside & $\mathrm{S}$ & BS4SS-1A & 460 & 443 & 98.87 & gi|480360049|gb|KC768764.1| \\
\hline $\begin{array}{l}\text { Microbacterium } \\
\text { phyllosphaerae }\end{array}$ & I & Bromus & Yachats & $\mathrm{RC}$ & YH2RC-4A & 460 & 445 & 99.33 & gi|110835896|emb|AM268326.1| \\
\hline $\begin{array}{c}\text { Microbacterium } \\
\text { phyllosphaerae strain }\end{array}$ & I & Bromus & Harbor Vista & $\mathrm{S}$ & HV11SS-3A & 460 & 436 & 100 & gi|387568139|gb|JQ684246.1| \\
\hline Oerskovia turbata strain & A & Bromus & Yachats & $\mathrm{RC}$ & YH3RC-10A & 460 & 440 & 100 & gi|118193595|gb|EF010749.1| \\
\hline Pantoea agglomerans strain & A & Festuca & Bob Creek Wayside & $S$ & BS8SS-3A & 460 & 449 & 98.22 & gi|440658039|gb|KC178591.1| \\
\hline Pantoea agglomerans strain & $\mathrm{B}$ & Festuca & Bob Creek Wayside & S & BS8SS-4A & 460 & 446 & 99.78 & gi|440658039|gb|KC178591.1| \\
\hline Pantoea ananatis & $\mathrm{C}$ & Festuca & Bob Creek Wayside & S & BS7SS-1A & 460 & 446 & 97.76 & gi|297373350|emb|FN691983.1| \\
\hline Uncultured Pantoea sp. & $\mathrm{D}$ & Bromus & Coos Bay & $\mathrm{RC}$ & CB2ARC-3A & 460 & 427 & 96.02 & gi|545342379|gb|KF505611.1| \\
\hline Pantoea sp. & $\mathrm{E}$ & Bromus & Coos Bay & $\mathrm{RC}$ & CB2ARC-2A & 460 & 360 & 83.06 & gi|353528968|gb|JN697999.1| \\
\hline Plantibacter sp. & A & Bromus & Harbor Vista & $\mathrm{RC}$ & HV12RC-1A & 460 & 443 & 85.1 & gi|289185531|gb|GU726494.1| \\
\hline Plantibacter flavus & $\mathrm{B}$ & Phalaris & Yachats & $\mathrm{RC}$ & YH1RC-2A & 460 & 438 & 100 & gi|590121428|emb|HE716918.1| \\
\hline Plantibacter flavus & B & Bromus & Yachats & $\mathrm{RC}$ & YH2RC-2A & 460 & 451 & 100 & gi|590121428|emb|HE716918.1| \\
\hline Plantibacter flavus & $\mathrm{B}$ & Descampsia & Yachats & $\mathrm{RC}$ & YH4RC-2A & 362 & 332 & 98.19 & gi|590121428|emb|HE716918.1| \\
\hline Plantibacter sp. & B & Hordeum & Coos Bay & $\mathrm{RC}$ & CB5RC-3A & 460 & 448 & 100 & gi|384070530|emb|HE662660.2| \\
\hline Plantibacter sp. & B & Bromus & Harbor Vista & $\mathrm{RC}$ & HV12RC-2A & 460 & 440 & 100 & gi|384070530|emb|HE662660.2| \\
\hline Plantibacter sp. & $\mathrm{B}$ & Bromus & Harbor Vista & $S$ & HV11SS-2A & 460 & 445 & 99.33 & gi|469665559|gb|KC355358.1| \\
\hline Pseudomonas sp. & A & Festuca & Bob Creek Wayside & $\mathrm{RC}$ & BS5RC-7A & 460 & 420 & 91.43 & gi|576735116|gb|KJ140081.1| \\
\hline Pseudomonas sp. & $\mathrm{B}$ & Festuca & Bob Creek Wayside & S & BS8SS-1A & 460 & 444 & 99.77 & gi|189231399|emb|FM161478.1| \\
\hline Pseudomonas sp. & $\mathrm{B}$ & Bromus & Harbor Vista & $\mathrm{RC}$ & HV11RC-1A & 460 & 443 & 99.55 & gi|189231399|emb|FM161478.1| \\
\hline Pseudomonas sp. & $\mathrm{B}$ & Bromus & Yachats & $\mathrm{RC}$ & YH3RC-7A & 460 & 442 & 100 & gi|189231399|emb|FM161478.1| \\
\hline Pseudomonas sp. & $\mathrm{B}$ & Festuca & Harbor Vista & $S$ & HV14SS-3A & 460 & 446 & 99.55 & gi|333774213|emb|FR775123.1| \\
\hline Pseudomonas sp. & $\mathrm{B}$ & Festuca & Harbor Vista & $\mathrm{RC}$ & HV6RC-2A & 460 & 451 & 99.56 & gi|636774081|gb|KJ569377.1| \\
\hline Pseudomonas sp. & $\mathrm{C}$ & Festuca & Harbor Vista & $\mathrm{RC}$ & HV14RC-2A & 460 & 454 & 99.78 & gi|189231281|emb|FM161360.1| \\
\hline Pseudomonas sp. & $\mathrm{C}$ & Ammophilia & Coos Bay & $\mathrm{RC}$ & CB3ARC-3A & 460 & 445 & 100 & gi|189231466|emb|FM161545.1| \\
\hline Pseudomonas sp. & $\mathrm{C}$ & Bromus & Bob Creek Wayside & S & BS2SS-1A & 460 & 448 & 100 & gi|189231466|emb|FM161545.1| \\
\hline Pseudomonas sp. & $\mathrm{C}$ & Descampsia & Yachats & S & YH4SS-1A & 460 & 447 & 100 & gi|189231466|emb|FM161545.1| \\
\hline Pseudomonas sp. & $\mathrm{C}$ & Festuca & Bob Creek Wayside & $\mathrm{RC}, \mathrm{L}$ & BS8RC-1A & 460 & 444 & 99.77 & gi|346218346|emb|FR727809.1| \\
\hline Pseudomonas gessardii strain & $\mathrm{D}$ & Festuca & Harbor Vista & $\mathrm{RC}$ & HV13RC-1A & 460 & 443 & 100 & gi|407280528|gb|JX514410.1| \\
\hline
\end{tabular}




\section{Continued}

\begin{tabular}{|c|c|c|c|c|c|c|c|c|c|}
\hline Pseudomonas sp. & $\mathrm{D}$ & Bromus & Yachats & RC & YH3RC-2A & 460 & 446 & 99.33 & gi|189231353|emb|FM161432.1| \\
\hline Pseudomonas sp. & $\mathrm{D}$ & Bromus & Yachats & $\mathrm{RC}$ & YH2RC-1A & 460 & 446 & 100 & gi|189231437|emb|FM161516.1| \\
\hline Pseudomonas sp. & $\mathrm{E}$ & Festuca & Bob Creek Wayside & $\mathrm{RC}$ & BS5RC-9A & 460 & 443 & 97.52 & gi|189231373|emb|FM161452.1| \\
\hline Pseudomonas abietaniphila & $\mathrm{F}$ & Ammophilia & Coos Bay & $\mathrm{RC}$ & CB3BRC-1B & 460 & 447 & 99.55 & gi|483932156|emb|HF952541.1| \\
\hline Pseudomonas anguilliseptica & G & Hordeum & Coos Bay & $\mathrm{RC}$ & CB5RC-2-1A & 460 & 446 & 95.29 & gi|99644529|emb|AM263523.1| \\
\hline Pseudomonas sp. & $\mathrm{H}$ & Festuca & Bob Creek Wayside & $\mathrm{RC}$ & BS5RC-8A & 460 & 448 & 99.78 & gi|189231373|emb|FM161452.1| \\
\hline Pseudomonas sp. & $\mathrm{H}$ & Bromus & Yachats & $\mathrm{RC}$ & $\begin{array}{c}\text { YH3RC-12C- } \\
\text { A }\end{array}$ & 460 & 447 & 100 & gi|189231373|emb|FM161452.1| \\
\hline $\begin{array}{c}\text { Pseudomonas viridiflava } \\
\text { strain }\end{array}$ & $\mathrm{H}$ & Bromus & Harbor Vista & $\mathrm{RC}$ & HV11RC-3A & 460 & 444 & 99.77 & gi|584594659|gb|KF898146.1| \\
\hline Pseudomonas sp. e & I & Hordeum & Coos Bay & $\mathrm{RC}$ & CB5RC-2-2B & 460 & 443 & 98.42 & gi|33150179|gb|AY336537.1| \\
\hline Pseudomonas fulva strain & $\mathrm{J}$ & Bromus & Coos Bay & $\mathrm{RC}$ & CB2BRC-2A & 460 & 451 & 99.78 & gi|71493091|gb|DQ122353.1| \\
\hline $\begin{array}{c}\text { Pseudomonas anguilliseptica } \\
\text { strain }\end{array}$ & $\mathrm{K}$ & Hordeum & Coos Bay & RC & CB5RC-4A & 460 & 451 & 98.67 & gi|406821997|gb|JX177687.1| \\
\hline Pseudomonas graminis strain & $\mathrm{L}$ & Festuca & Bob Creek Wayside & $\mathrm{RC}$ & BS5RC-5A & 460 & 444 & 98.65 & gi|343469120|gb|JN390962.1| \\
\hline Pseudomonas koreensis & M & Bromus & Coos Bay & RC & CB2BRC-1A & 460 & 441 & 99.77 & gi|397174178|emb|HE819905.1| \\
\hline $\begin{array}{c}\text { Pseudomonas moraviensis } \\
\text { strain }\end{array}$ & M & Festuca & Harbor Vista & $\mathrm{RC}$ & HV9RC-3A & 460 & 432 & 98.38 & gi|605052202|gb|KJ186949.1| \\
\hline Uncultured Pseudomonas sp. & M & Phalaris & Yachats & $\mathrm{RC}$ & YH6RC-1A & 460 & 448 & 99.55 & gi|34333932|gb|AY364050.1| \\
\hline Uncultured Ralstonia sp. & A & Phalaris & Bob Creek Wayside & $\mathrm{RC}$ & BS9RC-1B & 460 & 389 & 80.98 & gi|189305371|gb|EU704960.1| \\
\hline Rhizobium sp. & A & Phalaris & Yachats & $\mathrm{RC}$ & YH6RC-3A & 460 & 434 & 92.4 & gi|456371517|gb|KC494332.1| \\
\hline Rhizobium sp. & $\mathrm{B}$ & Festuca & Harbor Vista & RC & HV13RC-3A & 460 & 430 & 97.21 & gi|339521428|gb|JN030539.1| \\
\hline Rhizobiaceae bacterium & $\mathrm{C}$ & Festuca & Bob Creek Wayside & RC & BS7RC-2A & 460 & 443 & 99.77 & gi|114440446|gb|DQ860031.1| \\
\hline Rhizobiales bacterium & $\mathrm{D}$ & Ammophila & Harbor Vista & RC & HV7RC-1A & 446 & 405 & 99.51 & gi|296964105|gb|HM270510.1| \\
\hline Rhodococcus erythropolis & A & Phalaris & Yachats & RC & YH1RC-1A & 460 & 436 & 92.66 & gi|229002248|dbj|AB499800.1| \\
\hline Rhodococcus sp & $\mathrm{B}$ & Bromus & Coos Bay & $\mathrm{L}$ & CB2ALF-2A & 460 & 449 & 98.89 & gi|532529616|gb|KF494637.1| \\
\hline Uncultured Roseomonas sp. & A & Hordeum & Coos Bay & S & CB5SS-2B & 446 & 424 & 100 & gi|545345985|gb|KF509217.1| \\
\hline $\begin{array}{l}\text { Uncultured Sphingomonas } \\
\text { sp. }\end{array}$ & A & Bromus & Bob Creek Wayside & S & BS3SS-2A & 460 & 439 & 98.41 & gi|557520178|gb|KC907344.1| \\
\hline Stenotrophomonas rhizophila & A & Ammophila & Harbor Vista & $\mathrm{RC}$ & HV7RC-2A & 460 & 453 & 100 & gi|111073240|emb|AM282567.1| \\
\hline Stenotrophomonas sp. & $\mathrm{B}$ & Phalaris & Yachats & $\mathrm{RC}$ & YH1RC-4A & 460 & 452 & 100 & gi|333494190|gb|JF345182.1| \\
\hline $\begin{array}{c}\text { Uncultured } \\
\text { Stenotrophomonas sp. }\end{array}$ & $\mathrm{C}$ & Bromus & Harbor Vista & $\mathrm{RC}$ & HV11RC-4A & 460 & 447 & 99.55 & gi|545339907|gb|KF503139.1| \\
\hline $\begin{array}{l}\text { Stenotrophomonas rhizophila } \\
\text { strain }\end{array}$ & $\mathrm{D}$ & Festuca & Harbor Vista & $\mathrm{RC}$ & HV9RC-2A & 460 & 446 & 100 & gi|627787876|gb|CР007597.1| \\
\hline $\begin{array}{l}\text { Stenotrophomonas rhizophila } \\
\text { strain }\end{array}$ & $\mathrm{D}$ & Bromus & Yachats & $\mathrm{RC}$ & YH3RC-4A & 460 & 451 & 100 & gi|627787876|gb|CР007597.1| \\
\hline Uncultured bacterium clone & A & Phalaris & Bob Creek Wayside & $\mathrm{RC}$ & BS4RC-1A & 460 & 417 & 83.93 & gi|381149208|gb|JN835227.1| \\
\hline Uncultured bacterium clone & B & Festuca & Harbor Vista & RC & HV4RC-2A & 460 & 445 & 97.53 & gi|296963526|gb|HM269931.1| \\
\hline
\end{tabular}




\section{Continued}

\begin{tabular}{|c|c|c|c|c|c|c|c|c|c|}
\hline Uncultured bacterium clone & $\mathrm{C}$ & Ammophilia & Coos Bay & RC & CB3BRC-2A & 460 & 442 & 99.77 & gi|323370055|gb|HQ906067.1| \\
\hline $\begin{array}{l}\text { Xanthomonadaceae } \\
\text { bacterium }\end{array}$ & A & Lolium & Bob Creek Wayside & $\mathrm{L}$ & BS1LF-2A & 460 & 354 & 75.42 & gi|311919631|gb|HQ472388.1| \\
\hline $\begin{array}{c}\text { Xanthomonadaceae } \\
\text { bacterium }\end{array}$ & $\mathrm{B}$ & Festuca & Harbor Vista & $\mathrm{L}$ & HV13LF-1A & 460 & 444 & 100 & gi|322161858|gb|JF176453.1| \\
\hline $\begin{array}{l}\text { Xanthomonadaceae } \\
\text { bacterium }\end{array}$ & B & Festuca & Harbor Vista & $\mathrm{RC}$ & HV14RC-3A & 460 & 440 & 99.77 & gi|322161858|gb|JF176453.1| \\
\hline Pseudoxanthomonas sp. & $\mathrm{C}$ & Festuca & Harbor Vista & $\mathrm{L}$ & HV14LF-1A & 460 & 444 & 100 & gi|326369573|gb|HQ256838.1| \\
\hline Xanthomonas arboricola & $\mathrm{D}$ & Bromus & Harbor Vista & $\mathrm{RC}$ & HV12RC-3A & 460 & 448 & 100 & gi|629510152|dbj|AB911210.1| \\
\hline $\begin{array}{c}\text { Xanthomonas translucens } \\
\text { strain }\end{array}$ & $\mathrm{E}$ & Hordeum & Coos Bay & $S$ & CB5SS-1A & 460 & 444 & 100 & gi|443302145|gb|JX976312.1| \\
\hline $\begin{array}{c}\text { Xanthomonas translucens } \\
\text { strain }\end{array}$ & $\mathrm{E}$ & Lolium & Bob Creek Wayside & $\mathrm{L}$ & BS1LF-1A & 460 & 446 & 100 & gi|443302145|gb|JX976312.1| \\
\hline $\begin{array}{c}\text { Xanthomonas translucens } \\
\text { strain }\end{array}$ & $\mathrm{E}$ & Festuca & Harbor Vista & $\mathrm{RC}$ & HV13RC-2B & 460 & 446 & 100 & gi|443302145|gb|JX976312.1| \\
\hline
\end{tabular}

${ }^{*}$ Seq Designation letter signifies same bacterial isolate (by sequence) but also found in a different plant; ${ }^{* *} \mathrm{RC}=$ Root Crown, $\mathrm{S}=\mathrm{Stem}, \mathrm{L}=\mathrm{Leaf} ;{ }^{* * *}$ Seq ID: Location, Plant \#, TissueType - Isolate \#; Green Highlighted positive for ACC deaminase activity.

\section{Submit or recommend next manuscript to SCIRP and we will provide best} service for you:

Accepting pre-submission inquiries through Email, Facebook, LinkedIn, Twitter, etc. A wide selection of journals (inclusive of 9 subjects, more than 200 journals) Providing 24-hour high-quality service User-friendly online submission system Fair and swift peer-review system Efficient typesetting and proofreading procedure Display of the result of downloads and visits, as well as the number of cited articles Maximum dissemination of your research work

Submit your manuscript at: http://papersubmission.scirp.org/

Or contact ajps@scirp.org 